\title{
Participation of diverse actors and usage of traditional and local knowledge in local biodiversity strategies and action plans of Japanese municipalities
}

\author{
Mifuyu Ogawa $^{1}$, Masashi Soga ${ }^{2}$ and Takehito Yoshida ${ }^{1,3}$
}

\begin{abstract}
The participation of diverse actors and usage of traditional and local knowledge have been recognized as important for ecosystem management, including local biodiversity strategies and action plans (LBSAPs) implemented in municipalities. Assessing the effects and influences of the participation of diverse actors and usage of traditional and local knowledge requires analyses by a social-ecological system framework. This study aimed to clarify (1) how the participation of diverse actors and the recognition and usage of traditional knowledge that is passed down from generation to generation, and local knowledge that is unique to a local community were related to LBSAP actions and effects and (2) how various social and ecological factors were related with the participation of diverse actors and traditional and local knowledge. We conducted a questionnaire survey and obtained the data from 70 municipalities that have formulated LBSAPs, in addition to other existing data from various sources. We then performed a multiple regression analysis using the full model including all explanatory variables. A positive relationship was observed between the variables for the participation of diverse actors and traditional and local knowledge and the variables for the information sharing, deliberation processes, the evaluative and investment activities of LBSAPs. For example, deliberation process of an LBSAP was thought to have provided an opportunity to recognize and learn local knowledge. Consciousness of local knowledge and usage of traditional knowledge in an LBSAP were then associated with awareness of change toward biodiversity among citizens. The participation of diverse actors and usage of traditional and local knowledge were influenced by several ecological and social factors such as natural and secondary forests, agricultural lands, population and influential people. These results suggest that participation of diverse actors and usage of traditional and local knowledge have a significant role in the formulation of LBSAPs and their outcomes.
\end{abstract}

Key Words: diverse stakeholders; ecosystem management; SES framework; social-ecological system

\section{INTRODUCTION}

Knowledge and the participation of local residents are considered to be important in advancing ecosystem management (e.g., Pollnac et al. 2010, Robinson et al. 2016, Turnhout et al. 2016, Hill et al. 2020). Examples of a body of knowledge among local residents include both traditional knowledge that is passed down from generation to generation, and local knowledge that is unique to a local community, and it is thought that ecosystem management based on this knowledge provides an option that can supplement, or be implemented in a manner similar to, scientific knowledge (e.g., Berkes et al. 2000, Turner et al. 2000, IPBES 2013, Díaz et al. 2018, 2019). Indigenous and local knowledge is highly diverse, and exists at the interface between the enormous variety of ecosystems and cultural systems (Hill et al. 2020). Traditional knowledge is sometimes referred to as "indigenous" knowledge so as to remove the negative connotations associated with the term "traditional" (Berkes et al. 2000). According to Son et al. (2019), indigenous knowledge systems provide rationales for participatory approaches and the basis for local-level decision making in many rural communities. In contrast, traditional and local knowledge were formulated as a result of participatory approaches and passed on to the present population. However, traditional and local knowledge of ecosystem management by local residents is being lost as a result of the circumstances that surround society and changes in the natural environment (Berkes et al. 2000, Turner et al. 2000, Kai et al. 2014, Okui et al. 2021). Furthermore, a participatory approach that involves diverse actors is important in consensus building and decision making (e.g., de Groot et al. 2010, IPBES
2013, Robinson et al. 2016, Kok et al. 2017). The participation of various local stakeholders contributes not only to decision making for sustainable ecosystem management, but also to the empowerment of local individuals (Fraser et al. 2006). In this way, the participation of diverse actors and the usage of traditional and local knowledge are recognized as important elements in ecosystem management (e.g., Cinner et al. 2019).

In contrast to national biodiversity strategies and action plans, which are basic plans for biodiversity conservation and sustainable use at a national level, there are local biodiversity strategies and action plans (LBSAPs), which describe those at the local levels such as towns and cities. LBSAPs are recognized to be crucial when implementing the Convention on Biological Diversity in each country (Avlonitis et al. 2012).

LBSAPs have been formulated in cities and regions worldwide (Lee and Sung 2018). The directions of LBSAPs vary from region to region; Cape Town in South Africa created conservation plans that emphasized the construction of partnerships between implementing agencies, non-governmental organizations, research institutions, and the private sectors (Younge and Fowkes 2003); whereas Delhi in India has aimed for mainstreaming biodiversity in urban planning (Dhote and Mukherjee 2018). Pierce (2015) analyzed 48 LBSAPs in 17 countries and showed that these LBSAPs often mentioned land use and biodiversity conservation but also indicated plans focused on indigenous culture, such as in Auckland, New Zealand.

LBSAPs in Japan were specified in the basic strategy of the Third National Biodiversity Strategy of Japan established in 2007

${ }^{1}$ Department of General Systems Studies, Graduate School of Arts and Sciences, University of Tokyo, Japan, ${ }^{2}$ Graduate School of Agricultural and Life Sciences, University of Tokyo, Japan, ${ }^{3}$ Research Institute for Humanity and Nature, Kyoto, Japan 
(Ministry of the Environment 2014). The Basic Act on Biodiversity enacted in 2008 also obliges local governments to make efforts to formulate basic plans for biodiversity conservation and sustainable use as LBSAPs (Ministry of the Environment 2014, Oda and Oyama 2018). The formulation of LBSAPs is needed to implement effective policies fitted with the actual circumstances in local society and ecosystems (Ministry of the Environment 2014, Oda and Oyama 2018). Until the end of fiscal year 2016, LBSAPs were formulated by 125 local governments in 41 prefectures and 84 municipalities (17 ordinance-designated cities; Oda and Oyama 2018). Sakai et al. (personal communication) classified LBSAPs from 58 municipalities into four types according to their relationships among the population, area of cultivated land, and area of forest land.

Assessments of the effects and influences of participation of diverse actors and traditional and local knowledge in ecosystem management requires analysis using a social-ecological system framework that considers both local society and ecosystems. Focusing on both people and nature has been considered important for biodiversity conservation in recent years (Berkes et al. 2000, Turner et al. 2000, Berkes and Berkes 2009, Mace 2014, Joa et al. 2018, Cámara-Leret et al. 2019), and organic connections between social and ecological systems were suggested to be required to achieve sustainability (Rissman and Gillon 2017). The social-ecological system framework described by Ostrom (2009) and McGinnis and Ostrom (2014) is effective in simultaneously analyzing social and ecological elements in ecosystem management. This framework has been used in previous research on coastal and forest ecosystems (cf. Cinner et al. 2012, Partelow and Boda 2015, Jarzebski et al. 2016). For example, Cinner et al. (2012) stated that the co-management of stocks in small-scale fisheries was largely successful at meeting social and ecological goals, but institutional characteristics strongly influenced livelihood and compliance outcomes, yet had little effect on ecological conditions. As in this example, analyzing local ecosystem management with a social-ecological system framework is effective in investigating the effects of social factors on ecological factors, and vice versa.

To date, there have been few studies that used the social-ecological system framework (Ostrom 2009, McGinnis and Ostrom 2014) to analyze the impacts and effects of traditional and local knowledge (cf. Gutiérrez et al. 2011, Gurney et al. 2019). The effects and influences of participation of diverse actors have also been analyzed as elements of "Actors" or "Governance Systems" in a social-ecological system framework (cf. Gutiérrez et al. 2011, Cinner et al. 2012, Leslie et al. 2015, Gurney et al. 2019, Fujitani et al. 2020), but how the traditional and local knowledge held by diverse actors is recognized and used in ecosystem management is unclear. Therefore, there is insufficient understanding of how traditional and local knowledge held by diverse local actors impacts ecosystem management, and, by contrast, which types of natural environmental and social factors are involved in the recognition and use of traditional and local knowledge. These facts show the importance of positioning the participation of diverse actors and traditional and local knowledge and analyzing its impacts and effects.

Using a social-ecological system framework, we analyzed the diverse actors and traditional and local knowledge of 66 LBSAPs formulated by 70 municipalities in Japan. The two following research objectives were set: (1) clarifying how the participation of diverse actors and the recognition and usage of traditional and local knowledge were related to LBSAP actions and effects, and, conversely, (2) evaluating how various social and ecological factors were related with the participation of diverse actors and traditional and local knowledge. In this study, traditional knowledge is defined as the wisdoms and skills of ecosystem management and use of natural resources that are passed down from generation to generation. Here, traditional knowledge is used in the same sense as traditional ecological knowledge in Berkes et al. (2000). Local knowledge is defined as the wisdoms and skills of ecosystem management and use of natural resources that are unique to a local community whether it is transferred between generations or not.

\section{METHODS}

LBSAPs in Japan were formulated in 71 municipalities (the LBSAP in Amami-Oshima island was jointly created by five municipalities), corresponding to approximately $4 \%$ of all municipalities in Japan, as of February 2016. Variables were evaluated using the results of a questionnaire survey described below and from descriptions in LBSAPs, local government websites, and public administrative and research institutions' data to analyze discussions during the LBSAP formulation process, activities associated with LBSAPs, and the changes in awareness after LBSAP formulation (Table 1).

The social-ecological system (SES) framework by McGinnis and Ostrom (2014) was used to select variables for analysis. The variables in the SES framework by McGinnis and Ostrom (2014) were shown as first-tier and second-tier variables. In our study, the second-tier variables were further subdivided into third-tier variables, which were then analyzed. The participation of diverse actors was positioned in the "Number of Relevant Actors" and "Socioeconomic Attributes" within the second tier of the "Actors" variable in the SES framework. Meanwhile, traditional and local knowledge was placed in the third-tier variable of the "Knowledge of SES/Mental Models" within the second tier of "Actors."

\section{LBSAP data}

Questionnaire survey regarding $L B S A P S$

A questionnaire survey regarding LBSAPs was conducted in February 2016, whose respondents were government officials related to LBSAPs and LBSAP committee members in 71 municipalities that had formulated LBSAPs. Responses from 70 municipalities were obtained with 275 forms from local government officials (retrieval rate of 63\%) and 295 forms from LBSAP committee members who were officially appointed by the local government (retrieval rate of $34 \%$ ). No personal information was obtained and used in this study.

Questions included those for traditional knowledge passed down from generation to generation, by giving examples such as the cultivation of traditional crops, traditional forms of rice paddies such as terraced ones, and the traditional use of natural materials for rituals. Also, questions for local knowledge unique to a local community were included, by giving examples such as agricultural practices in accordance with a local certification system, local ecological management of landscapes based on local monitoring, 
Table 1. Variables of the social-ecological system framework used in this study according to McGinnis and Ostrom (2014).

\begin{tabular}{|c|c|c|c|c|}
\hline \multicolumn{3}{|c|}{ Variables in McGinnis \& Ostrom (2014) } & Variables used in this study & \multirow[b]{2}{*}{ Code } \\
\hline First-tier variables & Seco & ond-tier variables & Third-tier variables & \\
\hline \multirow{2}{*}{$\begin{array}{l}\text { Social, economic, and political } \\
\text { settings (S) }\end{array}$} & $\mathrm{S} 1$ & Economic development & Financial strength index & $\mathrm{S} 1-\mathrm{F}$ \\
\hline & $\mathrm{S} 2$ & Demographic trends & Population & S2-P \\
\hline \multirow[t]{10}{*}{ Resource systems (RS) } & $\begin{array}{l}\text { R- } \\
\text { S3 }\end{array}$ & Size of resource system & Area of plantation forest & RS31-P \\
\hline & & & Area of natural, secondary, and other forest & RS32-N \\
\hline & & & Area of cultivated meadow & $\mathrm{RS} 33-\mathrm{C}$ \\
\hline & & & Area of natural, secondary, and other grassland & RS34-N \\
\hline & & & Area of paddy field & RS35-P \\
\hline & & & Area of other cultivated land & $\mathrm{RS} 36-\mathrm{C}$ \\
\hline & & & Area of wetland and open water & RS37-M \\
\hline & & & Coast & $\mathrm{RS} 38-\mathrm{C}$ \\
\hline & $\begin{array}{l}\text { R- } \\
\text { S4 }\end{array}$ & Human-constructed facilities & Densely inhabited district & RS4-D \\
\hline & & Productivity of system & Net primary production & RS5-N \\
\hline \multirow[t]{3}{*}{ Resource units (RU) } & $\begin{array}{l}\text { R- } \\
\text { U4 }\end{array}$ & Economic value & Agricultural products & RU41-A \\
\hline & & & Woody products & RU42-W \\
\hline & & & Catch of fish & RU43-F \\
\hline \multirow[t]{7}{*}{ Governance systems (GS) } & GS2 & Nongovernment organizations & NPO participated in the LBSAP committee & GS2-N \\
\hline & GS3 & Network structure & Number of cooperated national and local governments & GS31-R \\
\hline & GS6 & Collective-choice rules & Presence of an implementation committee of LBSAP & GS6-C \\
\hline & GS7 & Constitutional-choice rules & Bylaw related to biodiversity conservation & GS7-B \\
\hline & GS8 & $\begin{array}{l}\text { Monitoring and sanctioning } \\
\text { rules }\end{array}$ & Monitoring of natural environment & GS81-M \\
\hline & & & Monitoring of ecosystem service & GS82-M \\
\hline & & & Monitoring by citizen & GS83-M \\
\hline \multirow[t]{11}{*}{ Actors (A) } & Al & Number of relevant actors & Number of municipal officials involved & A11-S \\
\hline & & & Number of LBSAP committee members & $\mathrm{A} 12-\mathrm{C}^{\dagger}$ \\
\hline & A2 & Socioeconomic attributes & Diversity of the LBSAP committee members & $\mathrm{A} 21-\mathrm{D}^{\dagger}$ \\
\hline & & & Diversity of experts in the LBSAP committee & $\mathrm{A} 22-\mathrm{E}^{\dagger}$ \\
\hline & & & Number of municipal sections involved & $\mathrm{A} 23-\mathrm{O}^{\dagger}$ \\
\hline & A5 & Leadership/entrepreneurship & Number of influential organizations and people & A51-G \\
\hline & & & Significant influence of the mayor & A52-L \\
\hline & A7 & $\begin{array}{l}\text { Knowledge of SES/mental } \\
\text { models }\end{array}$ & Consciousness of traditional knowledge & $\mathrm{A} 71-\mathrm{T}^{*}$ \\
\hline & & & Consciousness of local knowledge & A72-L* \\
\hline & & & Diversity of traditional knowledge & $\mathrm{A} 73-\mathrm{T}^{*}$ \\
\hline & & & Diversity of local knowledge & A74-L $\mathrm{L}^{*}$ \\
\hline \multirow[t]{15}{*}{ Action situations: Interactions (I) } & $\mathrm{I} 2$ & Information sharing & Announcement of the progress & I2-A \\
\hline & $\mathrm{I} 3$ & Deliberation processes & Number of meetings held in the LBSAP committee & I31-F \\
\hline & & & Informal meetings other than the LBSAP committee meetings & I32-M \\
\hline & & & Overtime works of municipal officials & I33-O \\
\hline & I5 & Investment activities & Actions reinforced by the LBSAP & I51-P \\
\hline & & & $\begin{array}{l}\text { Actions reinforced by the LBSAP (related to biodiversity and } \\
\text { environment) }\end{array}$ & I52-B \\
\hline & & & $\begin{array}{l}\text { Actions reinforced by the LBSAP (related to agriculture, forestry } \\
\text { and fishery) }\end{array}$ & I53-A \\
\hline & & & Actions with a newly allocated budget & I54- P \\
\hline & & & $\begin{array}{l}\text { Actions with a newly allocated budget (related to biodiversity and } \\
\text { environment) }\end{array}$ & I55-B \\
\hline & & & $\begin{array}{l}\text { Actions with a newly allocated budget (related to agriculture, } \\
\text { forestry and fishery) }\end{array}$ & I56-A \\
\hline & & & All Actions in LBSAP & I57-L \\
\hline & & & Inclusion of important ecosystems in the LBSAP & $\mathrm{I} 58-\mathrm{N}$ \\
\hline & & & Establishment of a biodiversity center & I59- C \\
\hline & I8 & Networking activities & $\begin{array}{l}\text { Establishment of new organizations or new participation of existing } \\
\text { organizations }\end{array}$ & I8-G \\
\hline & $\mathrm{I} 10$ & Evaluative activities & Activeness in evaluating actions of the LBSAP & I10-A \\
\hline \multirow[t]{2}{*}{$\rightarrow$ Outcomes $(\mathrm{O})$} & $\mathrm{O} 1$ & Outcomes & Extent of awareness change among citizens & $\mathrm{O} 1-\mathrm{C}$ \\
\hline & & & Effectiveness of the LBSAP to the society, economy, and daily life & $\mathrm{O} 2-\mathrm{U}$ \\
\hline
\end{tabular}

Variables related to participation of diverse actors.

Variables related to traditional and local knowledge. 
and unique practices for constructing ecological corridors and biotopes.

Extraction from LBSAPs and local government websites Attributes of local government sections, committee members, and officials associated with LBSAPs were extracted from the LBSAPs. We also assessed whether associated councils were established or whether ordinances were enacted after the LBSAP was formulated. The websites of local governments were used as confirmation when there was no description of councils or ordinances in the LBSAP.

Use of the LBSAP Review by the Biodiversity Strategy Division, Nature Conservation Bureau, Ministry of the Environment

We used the database of the LBSAP Review by the Biodiversity Strategy Division, Nature Conservation Bureau, Ministry of the Environment (https://www.env.go.jp/nature/biodic/lbsap/review. html). Data on the presence of local natural environmental surveys, surveys on ecosystem services, and whether these surveys were participatory for local residents were used.

\section{Ecological and social data other than LBSAPs}

Various publicly available data were used in this study. Data relating to forests, grasslands, and agricultural lands from the National Institute for Environmental Studies "Standardized land-use classification map for the whole of Japan" (https://www. nies.go.jp/biology/data/lu.html) were used. Population, financial strength index, and agricultural product data in 2010 were used from the municipality-specific population and economic data (https://www5.cao.go.jp/keizai-shimon/kaigi/special/future/keizaijinkou data.html) of the Cabinet Office statistical data. Municipality-specific fisheries and aquaculture production data from surveys of sea surface catch production of the Ministry of Agriculture, Forestry and Fisheries were used for 2010 catch data (https://www.e-stat.go.jp/stat-search/files?page $=1 \& l a y o u t=$ datalist\&toukei $=00500216 \&$ tstat $=000001015174 \&$ cycle $=7 \& y e a-$ $\underline{r}=20100 \&$ month $=0 \&$ tclass $1=000001042343 \&$ tclass $2=000001050844)$. Industrial statistics table ";municipal edition" data from the Ministry of Economy, Trade and Industry (https://www.meti.go. $\mathrm{jp} /$ statistics/tyo/kougyo/result-2.html) were used for the shipment value of wood and wood products, as well as furniture and the equipment manufacturing industry. Municipality-specific net primary production was calculated and provided by Drs. Michio Oguro and Takahiro Sasai based on Sasai et al. (2016).

\section{Analysis}

Each data set was aligned for each of the 70 municipalities, and the average for each municipality was used for the questionnaire results. Then, 50 variables were classified into "Social, Economic, and Political Settings," "Resource Systems," "Resource Units," "Governance Systems," "Actors," and "Interactions \& Outcomes," according to McGinnis and Ostrom (2014; Table 1). Detailed explanations of each variable are shown in Appendix 1.

A Z-transform $($ mean $=0$, variance $=1)$ was first applied to each variable. Then, correlation coefficients between the variables were calculated to eliminate the collinearity between them. The variables "area of plantation forest" and "net primary production" had a high correlation coefficient of over 0.8 , so only "area of plantation forest" was used as a variable in later analysis.
The data included some missing values ( $5.8 \%$ of the total) in the questionnaire responses and extractions from LBSAP. These missing values were complemented with multivariate imputation (1000 times). Data that underwent multivariate imputation were used to conduct a multiple regression analysis of the full model including all explanatory variables, with each of "Participation of Diverse Actors," "Traditional and Local Knowledge," and "Interactions \& Outcomes" variables as a response variable (Table 1). R (ver. 3.51) was used for analysis with the MICE library (van Buuren and Groothuis-Oudshoorn 2011).

\section{RESULTS}

Participation of diverse actors and traditional and local knowledge related to interactions and outcomes of LBSAPs The associations of interactions and outcomes of LBSAPs with the participation of diverse actors and traditional and local knowledge were detected in the statistical analysis. The relationship between other variables and interactions and outcomes is shown in Appendices 2 and 3.

A negative relationship was observed for the number of municipal sections involved and the diversity of traditional knowledge with the announcement of the progress of LBSAPs, relating to information sharing (Fig. 1). Meanwhile, a positive relationship was observed between the diversity of local knowledge and the announcement of the progress of LBSAPs (Fig. 1).

A positive tendency (marginally significantly) was observed for consciousness of local knowledge with the number of meetings held by the LBSAP committee, relating to deliberation processes (Appendix 2). A positive relationship was observed for the number of municipal officials involved in the formulation of the LBSAP and the consciousness of local knowledge with the hours of informal meetings other than the LBSAP committee formal meetings (Fig. 1). A positive relationship was also observed between the consciousness of local knowledge and the overtime work of municipal officials involved in the LBSAP (Fig. 1).

Positive and negative relationships were observed between the consciousness of traditional knowledge and consciousness of local knowledge, respectively, with the number of actions reinforced by the LBSAP, relating to investment activities (Fig. 2). A positive relationship was observed between the number of municipal sections involved and the number of all actions described in the LBSAP (Fig. 2). Positive tendencies were observed for the number of municipal officials involved in LBSAP and the consciousness of traditional knowledge with the extent to which important ecosystems in the LBSAP were included (Fig. 2). A positive tendency was observed between the diversity of the LBSAP committee members and the establishment of a biodiversity center related to a LBSAP (Fig. 2).

A positive relationship was observed between the consciousness of traditional knowledge and the activeness in evaluating actions of the LBSAP, relating to evaluative activities (Fig. 2). Positive relationships were observed for the consciousness of local knowledge and the diversity of traditional knowledge with the extent of awareness change among citizens, relating to outcomes (Fig. 3). 
Fig. 1. Results of the multiple regression analysis for variables related to information sharing and deliberation processes of the social-ecological system framework as response variables. Only the significant and marginally significant relationships with variables related to the participation of diverse actors and traditional and local knowledge are shown here. Full results are shown in Appendix 2.

I2-A: Announcement of the progress, I31-F: Number of meetings held in the local biodiversity strategies and action plans (LBSAPs) committee, I32-M: Informal meetings other than the LBSAP committee meetings, I33-O: Overtime work of municipal officials, A11-S: Number of municipal officials involved, A12-C: Number of LBSAP committee members, A23-O: Number of municipal sections involved, A72-L: Consciousness of local knowledge, A73-T: Diversity of traditional knowledge, A74-L: Diversity of local knowledge.

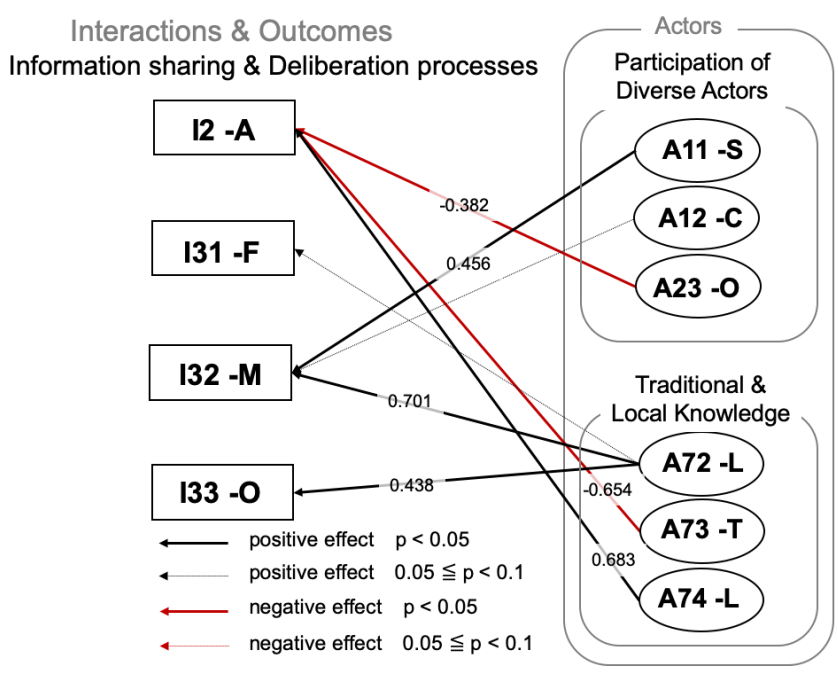

Variables relating to the participation of diverse actors

The participation of diverse actors was influenced by the variables in "Social, Economic, and Political Settings," "Resource Systems," "Resource Units," and "Actors," but not "Governance Systems" (Fig. 4). Of the participation of diverse actors in the LBSAP formulation process, a positive tendency (marginal significant) was observed between the number of LBSAP committee members with the presence of oceanic coast in a municipality (Fig. 4). Committee participation from fisheries actors was observed in such a municipality with coasts.

Negative and positive relationships were observed for the population of a municipality and the significant influence of the mayor with the diversity of the LBSAP committee members, respectively (Fig. 4). Major cities, including ordinance-designated cities, often do not have committee members related to primary industries such as farmers and fishermen, and tended to have more experts and NPO committee members.

Positive relationships were observed for the financial strength index and the area of natural, secondary, and other forests with
Fig. 2. Results of the multiple regression analysis for variables related to the investment and evaluative activities of the socialecological system framework as response variables. Only the significant and marginally significant relationships with variables related to the participation of diverse actors and traditional and local knowledge are shown here. Full results are shown in Appendix 2.

I51-P: Actions reinforced by the local biodiversity strategies and action plan (LBSAP), I57-L: All Actions in LBSAP, I58-N: Inclusion of important ecosystems in the LBSAP, I59-C:

Establishment of a biodiversity center, I10-A: Activeness in evaluating actions of the LBSAP, A11-S: Number of municipal officials involved, A21-D: Diversity of the LBSAP committee members, A23-O: Number of municipal sections involved, A71-T: Consciousness of traditional knowledge, A72-L: Consciousness of local knowledge, A73-T: Diversity of traditional knowledge.

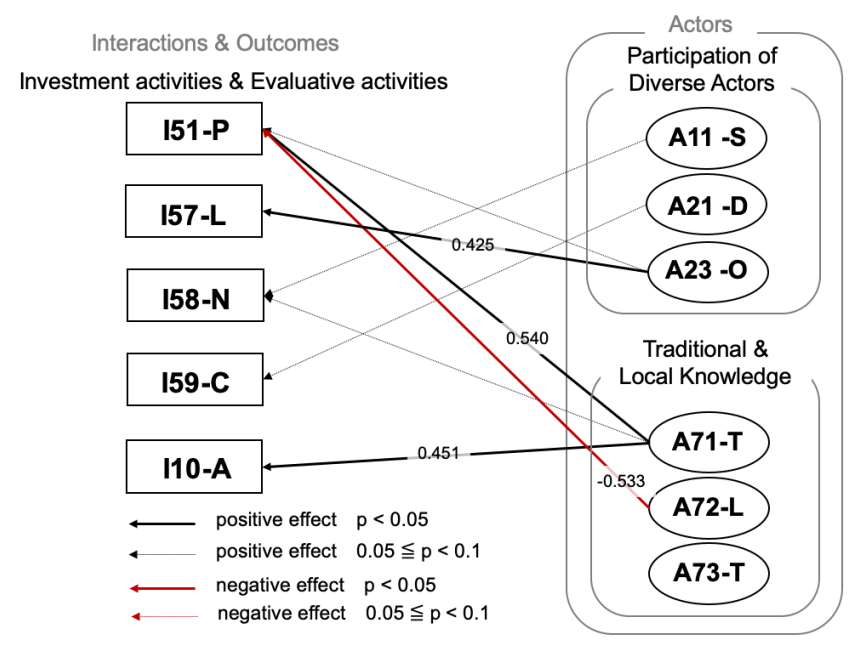

the number of municipal sections involved in the formulation of LBSAPs in each municipality (Fig. 4). The relationship between other variables and the participation of diverse actors is shown in Appendix 4.

Variables relating to traditional and local knowledge

The influences of the variables in "Resource Systems," "Resource Units," and "Actors," but not in "Social, Economic, and Political Settings" and "Governance Systems" were observed on traditional and local knowledge (Fig. 5). Positive relationships for the diversity of the LBSAP committee members and the number of influential organizations and people with the consciousness of traditional knowledge were observed (Fig. 5). A positive relationship was observed between the number of influential organizations and people and the consciousness of local knowledge as well (Fig. 5).

The diversity of traditional knowledge used in a LBSAP was significantly higher as the area of cultivated meadow was smaller (i.e., negative relationship; Fig. 5). On the other hand, 
Fig. 3. Results of the multiple regression analysis for variables related to outcomes of the social-ecological system framework as response variables. Only the significant and marginally significant relationships with variables related to the participation of diverse actors and traditional and local knowledge are shown here. Full results are shown in Appendix 2.

O1-C: Extent of awareness change among citizens, A72-L: Consciousness of local knowledge, A73-L: Diversity of traditional knowledge.

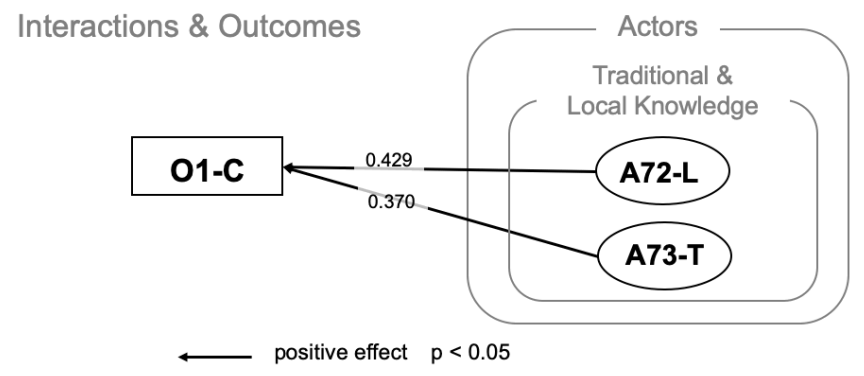

Fig. 4. Results of the multiple regression analysis for variables related to the participation of diverse actors as response variables. Only the significant and marginally significant relationships are shown here. Full results are shown in Appendix 4.

A12-C: Number of local biodiversity strategies and action plan (LBSAP) committee members, A21-D: Diversity of the LBSAP committee members, A23-O: Number of municipal sections involved, S1-F: Financial strength index, S2-P: Population, RS32-N: Area of natural, secondary, and other forest, RS33-N: Area of cultivated meadow, RS38-C: Coast, RU43-F: Catch of fish, A52-L: Significant influence of the mayor, A73-T:

Diversity of traditional knowledge, A74-L: Diversity of local knowledge.

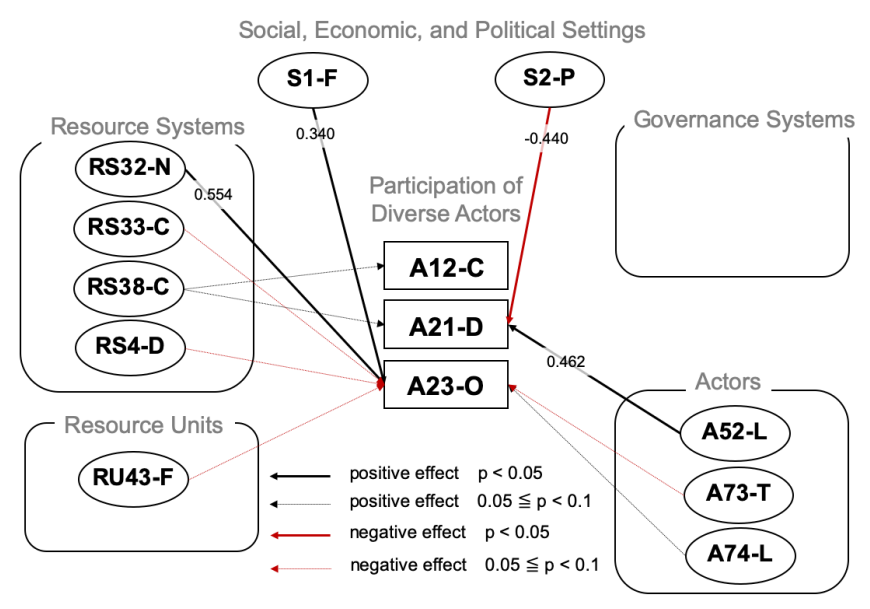

Fig. 5. Results of the multiple regression analysis for variables related to traditional and local knowledge as response variables. Only the significant and marginally significant relationships are shown here. Full results are shown in Appendix 5.

A71-T: Consciousness of traditional knowledge, A72-L: Consciousness of local knowledge, A73-T: Diversity of traditional knowledge, A74-L: Diversity of local knowledge, RS32-N: Area of natural, secondary, and other forests, RS33$\mathrm{N}$ : Area of cultivated meadow RS34-N: Area of natural, secondary, and other grasslands, RS35-P: Area of paddy field, RS36-C: Area of other cultivated land, RU41-A: Agricultural products, RU43-F: Catch of fish, A11-S: Number of municipal officials involved, A21-D: Diversity of the Local Biodiversity Strategies and Action Plan (LBSAP) committee members, A51G: Number of influential organizations and people.

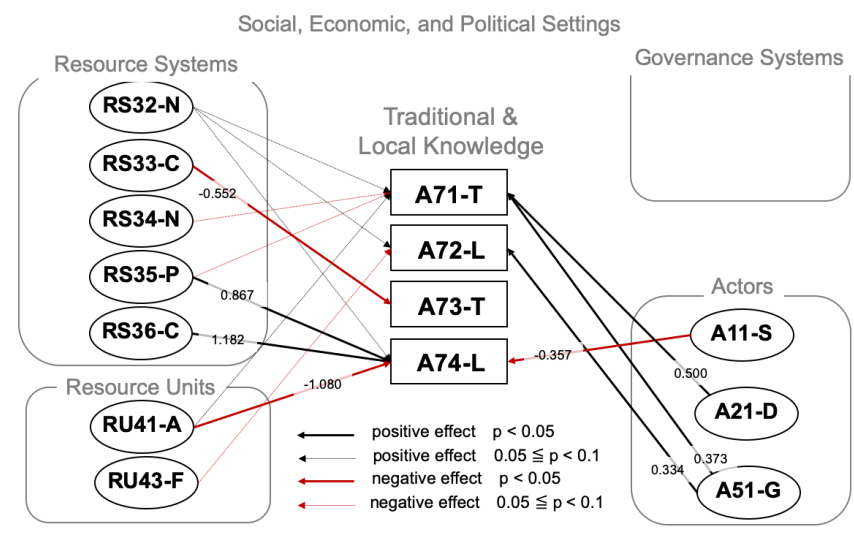

the diversity of local knowledge was positively related to the area of paddy fields and the area of other cultivated land. The diversity of local knowledge was also negatively related to the amount of agricultural products and the number of municipal officials involved in the LBSAPs (Fig. 5). The relationship between other variables and the recognition and use of traditional and local knowledge is shown in Appendix 5.

\section{DISCUSSION}

Effects brought about by the participation of diverse actors and traditional and local knowledge

Variables related to the deliberation process of LBSAP showed a positive relationship with variables for the participation of diverse actors and those related to traditional and local knowledge (Fig. 1). Specifically, there was a relationship between variables relating to the deliberation process (informal meetings other than the LBSAP committee meetings, the number of meetings held in the LBSAP committee, overtime work of municipal officials involved with the LBSAP), variables relating to the participation of diverse actors (number of officials who contributed to formulation, number of committees), and variables relating to traditional and local knowledge (consciousness of local knowledge; Fig. 1). The following relationships were thought to have been present between the deliberation process, participation of diverse actors, and traditional and local knowledge. The first was the possibility that 
many officials and committee members joined informal meetings other than those of the committee, which were one of the unofficial deliberation venues, and the consciousness of local knowledge among participants increased after long deliberations. The second was the possibility that stakeholders who already had a high consciousness of local knowledge joined the meetings and engaged in deliberations over a long period of time. According to Armitage et al. (2011), deliberations were said to lead to the sharing of various knowledge and the usage of specialized knowledge by acting as a learning opportunity for actors in various positions. According to Reed (2008), the participation of diverse stakeholders was essential for comprehensively incorporating information in the decision making of environmental problems, and this was said to increase the quality of decision making. Various types of information were exchanged among many stakeholders during deliberations for the formulation of LBSAP, and this may have served as opportunities among stakeholders who participated in these deliberations to share the importance of local knowledge.

Variables related to investment activities of LBSAP were positively related to those for the participation of diverse actors (Fig. 2). Particularly, the more municipal sections that were involved in the LBSAP formulation, the more LBSAP actions were taken (Fig. 2). LBSAPs in Isumi City (Chiba Prefecture) or Akiruno City (Tokyo Metropolitan) had many sections that were in charge of activities, and those in agriculture, forestry, and education were involved, in addition to those in charge of biodiversity conservation. From these aspects, it was thought that the number of LBSAP actions increased when multiple sections brought in their own actions. To date, biodiversity conservation and other fields (e.g., agriculture, forestry, fisheries, and tourism) have often been indicated as having conflicting interests (e.g., Henle et al. 2008, Rauschmayer et al. 2008, Redpath et al. 2013). However, LBSAPs with a large number of actions were thought to have been formulated through the cooperation of sections with interests possibly conflicting those of biodiversity conservation. Bodin (2017) stated that actors in various positions cooperating and learning is important in terms of responding to environmental problems, and our results are consistent with this.

Both positive and negative relationships were observed between variables relating to investment activities of LBSAP and variables relating to traditional and local knowledge (Fig. 2). Specifically, the number of actions reinforced by the LBSAP had a positive relationship with the consciousness of traditional knowledge, but had a negative relationship with the consciousness of local knowledge (Fig. 2). Traditional knowledge has been passed down across generations and is retained by individuals and local communities (Berkes et al. 2000). Traditional knowledge addressed in the questionnaire survey in this study includes diverse knowledge and techniques, such as agricultural methods, fishing methods, hunting methods, biological resources use, festivals, and playing. These span a wide range of fields when matched to administrative fields, and may be related to the increase in the number of strengthened actions. Meanwhile, local knowledge addressed in the questionnaire survey in this study was limited, and included techniques such as agriculture, forestry, and fisheries based on certification systems, and information on wildlife corridors and biotopes. Therefore, this may have strengthened only limited actions, possibly resulting in the negative relationship between the number of strengthened actions and the consciousness of local knowledge.

Furthermore, sharing information related to LBSAPs had a negative relationship with variables related to the participation of diverse actors and both negative and positive relationships with variables relating to traditional and local knowledge (Fig. 1). A large number of sections related to the formulation of LBSAPs resulted in differences in implementation efforts and durations between the various actions proposed by sections, which may have made announcement of the progress of a LBSAP difficult. Also, the subjects of traditional knowledge addressed in our questionnaire survey were wide ranging, and it was thought that they were not directly related to the administrative sections, which may have led to a lack of announcement of progress. Meanwhile, local knowledge addressed in our questionnaire survey was within a limited range, which could be incorporated into actions of the administrative section. Therefore, an increased usage of local knowledge may have made announcement of progress easier. The variable for evaluative activities for actions was positively related to the consciousness of traditional knowledge (Fig. 2); however, the specific relationships between them were not clear.

The extent of awareness change among citizens toward biodiversity, an outcomes variable in our analysis, was positively related to the consciousness of local knowledge and the diversity of traditional knowledge (Fig. 3). The consciousness of local knowledge was also positively related to the hours of informal meetings and the overtime work of municipal officials involved in the LBSAP (Fig. 1). It was thought that there was a possibility that committee members and municipal officials learned local knowledge through long conversations and work when formulating a LBSAP, which led to changes in awareness among citizens. Furthermore, there was a positive relationship between the diversity of traditional knowledge and the extent of awareness change among citizens. Thus, it was thought that even in cases in which it was difficult to incorporate traditional knowledge into a LBSAP (Appendix 6), it was still possible to bring about changes in awareness among citizens. Traditional and local knowledge is deeply related to the local culture and spirituality and is nurtured in each region (e.g., Berkes et al. 2000, Turner et al. 2000, Berkes and Berkes 2009, Joa et al. 2018, Cámara-Leret et al. 2019). LBSAPs provide an opportunity to once again recognize and learn traditional and local knowledge, and it was thought that awareness change among citizens toward biodiversity was brought about by recognizing and utilizing local and traditional knowledge.

\section{Factors relating to the participation of diverse actors}

Variables relating to the participation of diverse actors had positive and negative relationships with both ecological and socioeconomic factors (Fig. 4). Regarding the variables relating to the participation of diverse actors, the number of committee members only had marginally significant positive relationships with the presence of coasts among ecological factors (Fig. 4). Municipalities with oceanic coasts often included fisheries actors as committee members, and it was thought that the number of committee members increased with their participation.

The diversity of committee members also had a weak positive relationship with the presence of coasts, and it was thought that 
the participation of fisheries actors increased the diversity of committee members. However, the diversity of committees had a stronger correlation with the socioeconomic factors of population or the significant influence of the mayor (Fig. 4). In cities with large populations, there are few people engaged in agriculture, forestry, or fisheries, so their LBSAP committees are likely to consist of academic experts, NPO personnel, and a few selected citizens, leading to the low diversity of committee members. These committees were often formed by academic experts, NPO officials, and publicly recruited members, and the diversity of committee members was not high. Meanwhile, when the mayor takes the leadership and directly influences the LBSAP formulation, the diversity of committee members would have increased.

The number of sections involved in the formulation of LBSAPs tended to be related to various variables, with a positive relationship with the financial strength index and the areas of natural and secondary forests (Fig. 4). Municipalities whose financial strength index exceeded 1 and that have a comfortable amount of financial resources counted 16, including Nagoya City, Yokohama City, Kawasaki City, Fuchu City, Minato ward, and Tokai village. These municipalities had a maximum of 14 sections cooperating to formulate LBSAPs, and this may have been related to the fact that ample financial resources were available to them. Meanwhile, municipalities with areas of natural and secondary forests over $40 \mathrm{~km}^{2}$ (e.g., Sapporo City, Iwaki City, Sado City, Matsumoto City, and Shizuoka City) had a maximum of 11 sections cooperating to formulate LBSAPs. Municipalities with a large area of natural and secondary forests and thus an abundance of nature may have had the duties of many sections related to LBSAPs.

\section{Factors relating to traditional and local knowledge}

Variables relating to traditional and local knowledge showed both positive and negative relationships with ecological and socioeconomic factors (Fig. 5). The consciousness of traditional knowledge had positive relationships with the diversity of committee members and the number of influential people and organizations involved in LBSAP formulation (Fig. 5). This may indicate that when the diversity of committee members and the number of influential people and organizations were high, the committee included those who were highly conscious of traditional knowledge.

The consciousness of local knowledge also had a positive relationship with the number of influential people and organizations involved in the formulation of LBSAPs (Fig. 5). It may be because people who were highly conscious of local knowledge were included among influential people and organizations involved in the formulation of LBSAPs.

The diversity of traditional knowledge used in LBSAP was higher in municipalities without coasts (Fig. 5). Descriptions relating to oceans or fisheries in LBSAPs were lower when compared to descriptions of agricultural lands or forestry. According to the Ministry of the Environment (2017), there were only two municipalities that mentioned fisheries activities in their LBSAPs. This may also simply reflect the weak links between LBSAPs and marine conservation or fisheries.
The diversity of local knowledge utilized in LBSAPs had positive relationships with the area of paddy fields and the area of other cultivated land such as vegetable fields and orchards, and negative relationships with the number of officials who contributed to the formulation of LBSAPs and the amount of agricultural products (Fig. 5). It was thought that local knowledge related to agriculture was actively utilized, whereas municipalities that were conducting intensive agriculture and thus producing high amounts of agricultural products, may not have used much local knowledge. Furthermore, increases in the number of officials involved in the formulation of LBSAPs did not necessarily result in an increased diversity of local knowledge.

\section{CONCLUSION}

It was thought that the consciousness of local knowledge among participants may have increased during the formulation of LBSAPs when officials and committee members communicated in informal meetings other than the LBSAP committee formal meetings. Meanwhile, actors who were already highly conscious of local knowledge joining informal meetings may have resulted in deliberations over a longer period of time. The importance of local knowledge was recognized as a result of having opportunities for people in various positions to speak with one another, and this was expected to lead to the usage of local knowledge in LBSAPs. There are few descriptions of the fisheries in LBSAPs, but the diversity of participants increased as a result of actors in the fisheries taking part in the formulation and revision of LBSAPs. This may have led to further opportunities to learn traditional and local knowledge.

Consciousness of the importance of traditional and local knowledge was associated with several variables related to deliberation processes, investment activities, evaluative activities, and outcomes in LBSAPs. Although the importance of traditional and local knowledge in LBSAPs was commonly recognized among local government officials and LBSAP committee members, the traditional and local knowledge was not incorporated into LBSAPs because of the lack of information about the knowledge and not knowing how to use the knowledge in LBSAPs (Appendix 6). Thus, it is important for a municipality that is planning to develop a new LBSAP or revise the existing LBSAP to collect and learn traditional and local knowledge by promoting discussions and exchanges among diverse actors from different sections related to biodiversity conservation, agriculture, forestry and fisheries, and to reflect the results of discussions in the LBSAP.

Our results suggest that the consciousness of local knowledge can emerge through the process of informal communication, although we could not examine more details of this process in this study, such as who the knowledge holders were and with whom the knowledge was shared. We also found that the diversity of local knowledge used in LBSAPs had a positive relationship with the area of agricultural land and a positive tendency with the area of natural and secondary forests (Fig. 5). These relationships between local knowledge and the natural environment remain to be studied in details, although traditional and local knowledge has been in decline (Berkes et al. 2000, Turner et al. 2000, Kai et al. 2014, Okui et al. 2021) and if the knowledge becomes extinct, ecosystem management would not be able to take advantage of that knowledge. On the other hand, if the 
natural environment is degraded, the traditional and local knowledge would not be so useful after all. When a LBSAP is about to be newly developed or revised, we recommend that the traditional and local knowledge associated with ecosystem management be explicitly incorporated and shared among diverse actors and citizens.

Responses to this article can be read online at: https://www.ecologyandsociety.org/issues/responses. php/12612

\section{Acknowledgments:}

We thank anonymous reviewers for their helpful comments to improve the manuscript. We would like to express our deep gratitude to the officials of Chiba Prefecture, Isumi City, Noda City, Nagareyama City, and Sado City for their cooperation in the pretest and interview surveys conducted prior to the questionnaire survey. We would like to extend our gratitude to all municipal officials and LBSAP committee members who responded to our questionnaire. The questionnaire was jointly created by Kosuke Oyama of Keio University, Yuuki Oda of Nihon University, and Yasuo Takahashi of IGES; net primary production was calculated by Michio Oguro and Takahiro Sasai; Kaori Okui and Yoko Imai were involved in the creation of the questionnaire and provided useful advice, and Chinatsu Zakouji cooperated with the distribution and retrieval of the questionnaire; we would like to extend our thanks to them. This research was supported by the Environment Research and Technology Development Fund [S-15-2(3) Predicting and Assessing Natural Capital and Ecosystem Services (PANCES): S-15-2(3) JPMEERF16S11507] of the Ministry of the Environment, Japan and the NIHU Transdisciplinary Project "Change of Local Communities and Reconstruction of Community Cultures after Disasters in Japanese Archipelago."

\section{Data Availability:}

The data that support the findings of this study are openly available in the supplementary materials.

\section{LITERATURE CITED}

Armitage, D., F. Berkes, A. Dale, E. Kocho-Schellenberg, and E. Patton. 2011. Co-management and the co-production of knowledge: learning to adapt in Canada's Arctic. Global Environmental Change 21(3):995-1004. https://doi.org/10.1016/ j.gloenvcha.2011.04.006

Avlonitis, G., C. Doll, R. Galt, A. Mader, R. Moreno-Peñaranda, S. Patrickson, J. A. P. de Oliveira, and W. Shih. 2012. Local biodiversity strategy and action plan guidelines: an aid to municipal planning and biodiversity conservation. Cities Biodiversity Center, Century City, Cape Town, South Africa. [online] URL: https://cbc.iclei.org/tools/

Berkes, F., and M. K. Berkes. 2009. Ecological complexity, fuzzy logic, and holism in indigenous knowledge. Futures 41(1):6-12. http://dx.doi.org/10.1016/j.futures.2008.07.003
Berkes, F., J. Colding, and C. Folke. 2000. Rediscovery of traditional ecological knowledge as adaptive management. Ecological Applications 10(5):1251-1262. https://doi. org/10.1890/1051-0761(2000)010[1251:ROTEKA]2.0.CO;2

Bodin, Ö. 2017. Collaborative environmental governance: achieving collective action in social-ecological systems. Science 357(6352):eaan1114. https://doi.org/10.1126/science.aan1114

Cámara-Leret, R., M. A. Fortuna, and J. Bascompte. 2019. Indigenous knowledge networks in the face of global change. Proceedings of the National Academy of Sciences 116 (20):9913-9918. https://doi.org/10.1073/pnas.1821843116

Cinner, J. E., J. D. Lau, A. G. Bauman, D. A. Feary, F. A. Januchowski-Hartley, C. A. Rojas, M. L. Barnes, B. J. Bergseth, E. Shum, R. Lahari, J. Ben, and N. A. J. Graham. 2019. Sixteen years of social and ecological dynamics reveal challenges and opportunities for adaptive management in sustaining the commons. Proceedings of the National Academy of Sciences 116 (52):26474-26483. https://doi.org/10.1073/pnas.1914812116

Cinner, J. E., T. R. McClanahan, M. A. MacNeil, N. A. J. Graham, T. M. Daw, A. Mukminin, D. A. Feary, A. L. Rabearisoa, A. Wamukota, N. Jiddawi, S. J. Campbell, A. H. Baird, F. A. Januchowski-Hartley, S. Hamed, R. Lahari, T. Morove, and J. Kuange. 2012. Comanagement of coral reef social-ecological systems. Proceedings of the National Academy of Sciences 109 (14):5219-5222. https://doi.org/10.1073/pnas.1121215109

de Groot, R. S., R. Alkemade, L. Braat, L. Hein, and L. Willemen. 2010. Challenges in integrating the concept of ecosystem services and values in landscape planning, management and decision making. Ecological Complexity 7(3):260-272. https://doi. org/10.1016/j.ecocom.2009.10.006

Dhote, M., and D. Mukherjee. 2018. Co-benefits of urban biodiversity. Pages 211-241 in M. Sethi and J. A. P. de Oliveira, editors. Mainstreaming climate co-benefits in Indian cities: posthabitat III innovations and reforms. Springer, Singapore. https:// doi.org/10.1007/978-981-10-5816-5_9

Díaz, S., U. Pascual, M. Stenseke, B. Martín-López, R. T. Watson, Z. Molnár, R. Hill, K. M. A. Chan, I. A. Baste, K. A. Brauman, S. Polasky, A. Church, M. Lonsdale, A. Larigauderie, P. W. Leadley, A. P. E. van Oudenhoven, F. van der Plaat, M. Schröter, S. Lavorel, Y. Aumeeruddy-Thomas, E. Bukvareva, K. Davies, S. Demissew, G. Erpul, P. Failler, C. A. Guerra, C. L. Hewitt, H. Keune, S. Lindley, and Y. Shirayama. 2018. Assessing nature's contributions to people. Science 359(6373):270-272. https://doi. org/10.1126/science.aap8826

Díaz, S., J. Settele, E. S. Brondízio, H. T. Ngo, J. Agard, A. Arneth, P. Balvanera, A. K. Brauman, S. H. M. Butchart, K. M. A. Chan, L. A. Garibaldi, K. Ichii, J. Liu, S. M. Subramanian, G. F. Midgley, P. Miloslavich, Z. Molnár, D. Obura, A. Pfaff, S. Polasky, A. Purvis, J. Razzaque, B. Reyers, R. R. Chowdhury, Y. Shin, I. Visseren-Hamakers, K. J. Willis, and C. N. Zayas. 2019. Pervasive human-driven decline of life on Earth points to the need for transformative change. Science 366(6471):eaax3100. https://doi. org $/ 10.1126 /$ science.aax3100

Fraser, E. D. G., A. J. Dougill, W. E. Mabee, M. Reed, and P. McAlpine. 2006. Bottom up and top down: analysis of 
participatory processes for sustainability indicator identification as a pathway to community empowerment and sustainable environmental management. Journal of Environmental Management 78(2):114-127. https://doi.org/10.1016/j.jenvman.2005.04.009

Fujitani, M. L., C. Riepe, T. Pagel, M. Buoro, F. Santoul, R. Lassus, J. Cucherousset, and R. Arlinghaus. 2020. Ecological and social constraints are key for voluntary investments into renewable natural resources. Global Environmental Change 63:102125. https://doi.org/10.1016/j.gloenvcha.2020.102125

Gurney, G. G., E. S. Darling, S. D. Jupiter, S. Mangubhai, T. R. McClanahan, P. Lestari, S. Pardede, S. J. Campbell, M. Fox, W. Naisilisili, N. A. Muthiga, S. D'agata, K. E. Holmes, and N. A. Rossi. 2019. Implementing a social-ecological systems framework for conservation monitoring: lessons from a multi-country coral reef program. Biological Conservation 240:108298. https://doi. org/10.1016/j.biocon.2019.108298

Gutiérrez, N. L., R. Hilborn, and O. Defeo. 2011. Leadership, social capital and incentives promote successful fisheries. Nature 470(7334):386-389. https://doi.org/10.1038/nature09689

Henle, K., D. Alard, J. Clitherow, P. Cobb, L. Firbank, T. Kull, D. McCracken, R. F. A. Moritz, J. Niemelä, M. Rebane, D. Wascher, A. Watt, and J. Young. 2008. Identifying and managing the conflicts between agriculture and biodiversity conservation in Europe-review. Agriculture, Ecosystems \& Environment 124 (1-2):60-71. https://doi.org/10.1016/j.agee.2007.09.005

Hill, R., Ç. Adem, W. V. Alangui, Z. Molnár, Y. AumeeruddyThomas, P. Bridgewater, M. Tengö R. Thaman, C. Y. Adou Yao, F. Berkes, et al. 2020. Working with indigenous, local and scientific knowledge in assessments of nature and nature's linkages with people. Current Opinion in Environmental Sustainability 43:8-20. https://doi.org/10.1016/j.cosust.2019.12.006

Intergovernmental Science-Policy Platform on Biodiversity and Ecosystem Services (IPBES). 2013. The contribution of indigenous and local knowledge systems to IPBES: building synergies with science. UNESCO, Paris, France. [online] URL: https://www.besnet.world/sites/default/files//mediafile/The $\%$ 20Contribution $\% 20$ of $\% 20$ local $\% 20$ and $\% 20$ indiogenous $\% 20$ knowledge $\%$ 20to $\% 20$ Ipbes.pdf

Jarzebski, M.P., V. Tumilba, and H. Yamamoto. 2016. Application of a tri-capital community resilience framework for assessing the social-ecological system sustainability of community-based forest management in the Philippines. Sustainability Science 11:307-320. https://doi.org/10.1007/ s11625-015-0323-7

Joa, B., G. Winkel, and E. Primmer. 2018. The unknown known - A review of local ecological knowledge in relation to forest biodiversity conservation. Land Use Policy 79:520-530. https:// doi.org/10.1016/i.landusepol.2018.09.001

Kai, Z., T. S. Woan, L. Jie, E. Goodale, K. Kitajima, R. Bagchi, and R. D. Harrison. 2014. Shifting baselines on a tropical forest frontier: extirpations drive declines in local ecological knowledge. PLoS ONE 9(1):e86598. https://doi.org/10.1371/journal.pone.0086598

Kok, M. T. J., K. Kok, G. D. Peterson, R. Hill, J. Agard, and S. R. Carpenter. 2017. Biodiversity and ecosystem services require
IPBES to take novel approach to scenarios. Sustainability Science 12:177-181. https://doi.org/10.1007/s11625-016-0354-8

Lee, H.-J. and K. Sung. 2018. Analysis of domestic and foreign local biodiversity strategies and action plan (LBSAP) using semantic network analysis. Journal of Environmental Impact Assessment 27(1):92-104. https://doi.org/10.14249/eia.2018.27.1.92

Leslie, H. M., X. Basurto, M. Nenadovic, L. Sievanen, K. C. Cavanaugh, J. J. Cota-Nieto, B. E. Erisman, E. Finkbeiner, G. Hinojosa-Arango, M. Moreno-Báez, S. Nagavarapu, S. M. W. Reddy, A. Sánchez-Rodríguez, K. Siegel, J. J. UlibarriaValenzuela, A. Hudson Weaver, and O. Aburto-Oropeza. 2015. Operationalizing the social-ecological systems framework to assess sustainability. Proceedings of the National Academy of Sciences 112(19):5979-5984. https://doi.org/10.1073/pnas.1414640112

Mace, G. M. 2014. Whose conservation? Science 345 (6204):1558-1560. https://doi.org/10.1126/science.1254704

McGinnis, M. D., and E. Ostrom, 2014. Social-ecological system framework: initial changes and continuing challenges. Ecology and Society 19(2):30. https://doi.org/10.5751/es-06387-190230

Ministry of the Environment. 2014. Guideline for formulating local biodiversity strategies and action plans (Revised edition). [Title translated from the Japanese.] Global Biodiversity Strategy Office, Biodiversity Strategy Division, Nature Conservation Bureau, Ministry of the Environment, Tokyo, Japan.

Ministry of the Environment. 2017. Review of the local biodiversity strategies and action plans. [Title translated from the Japanese.] Ministry of the Environment, Tokyo, Japan. [online] URL: https://www.env.go.jp/nature/biodic/lbsap/review.html

Oda, Y., and K. Oyama. 2018. Analysis of the local biodiversity strategies and action plans formulation factors: verification of policy diffusion models in municipalities. Journal of Public Policy Studies: Official Journal of the Public Policy Studies Association 18:90-102. [Translated from the Japanese.]

Okui, K., Y. Sawada, and T. Yoshida. 2021. "Wisdom of the elders" or "loss of experience" as a mechanism to explain the decline in traditional ecological knowledge: a case study on Awaji Island, Japan. Human Ecology 49:353-362. https://doi. org/10.1007/s10745-021-00237-W

Ostrom, E. 2009. A general framework for analyzing sustainability of social-ecological systems. Science 325 (5939):419-422. https://doi.org/10.1126/science.1172133

Partelow, S., and C. Boda. 2015. A modified diagnostic socialecological system framework for lobster fisheries: case implementation and sustainability assessment in Southern California. Ocean \& Coastal Management 114:204-217. http:// dx.doi.org/10.1016/j.ocecoaman.2015.06.022

Pierce, J. 2015. Planning for urban biodiversity in a divided world. Thesis. Cornell University, Ithaca, New York, USA.

Pollnac, R., P. Christie, J. E. Cinner, T. Dalton, T. M. Daw, G. E. Forrester, N. A. J. Graham, and T. R. McClanahan. 2010. Marine reserves as linked social-ecological systems. Proceedings of the National Academy of Sciences 107(43):18262-18265. http://dx. doi.org/10.1073/pnas.0908266107 
Rauschmayer, F., H. Wittmer, and A. Berghöfer. 2008. Institutional challenges for resolving conflicts between fisheries and endangered species conservation. Marine Policy 32 (2):178-188. https://doi.org/10.1016/j.marpol.2007.09.008

Redpath, S. M., J. Young, A. Evely, W. M. Adams, W. J. Sutherland, A. Whitehouse, A. Amar, R. A. Lambert, J. D. C. Linnell, A. Watt, and R. J. Gutiérrez. 2013. Understanding and managing conservation conflicts. Trends in Ecology \& Evolution 28(2):100-109. https://doi.org/10.1016/j.tree.2012.08.021

Reed, M. S. 2008. Stakeholder participation for environmental management: a literature review. Biological Conservation 141 (10):2417-2431. https://doi.org/10.1016/j.biocon.2008.07.014

Rissman, A. R., and S. Gillon. 2017. Where are ecology and biodiversity in social-ecological systems research? A review of research methods and applied recommendations. Conservation Letters 10(1):86-93. https://doi.org/10.1111/conl.12250

Robinson, C. J., K. Maclean, R. Hill, E. Bock, and P. Rist. 2016. Participatory mapping to negotiate indigenous knowledge used to assess environmental risk. Sustainability Science 11:115-126. https://doi.org/10.1007/s11625-015-0292-x

Sasai, T., H. Obikawa, K. Murakami, S. Kato, T. Matsunaga, and R. R. Nemani. 2016 Estimation of net ecosystem production in Asia using the diagnostic-type ecosystem model with a $10 \mathrm{~km}$ gridscale resolution. Journal of Geophysical Research Biogeoscience 121(6):1484-1502. https://doi.org/10.1002/2015JG003157

Son, H. N., D. T. L. Chi, and A. Kingsbury. 2019. Indigenous knowledge and climate change adaptation of ethnic minorities in the mountainous regions of Vietnam: a case study of the Yao people in Bac Kan Province. Agricultural Systems 176:102683. https://doi.org/10.1016/j.agsy.2019.102683

Turner, N. J., M. B. Ignace, and R. Ignace. 2000. Traditional ecological knowledge and wisdom of aboriginal peoples in British Columbia. Ecological Applications 10(5):1275-1287. https://doi. org/10.1890/1051-0761(2000)010[1275:tekawo]2.0.co;2

Turnhout, E., A. Dewulf, and M. Hulme. 2016. What does policyrelevant global environmental knowledge do? The cases of climate and biodiversity. Current Opinion in Environmental Sustainability 18:65-72. https://doi.org/10.1016/j.cosust.2015.09.004

van Buuren, S., and K. Groothuis-Oudshoorn. 2011. mice: Multivariate imputation by chained equations in R. Journal of Statistical Software 45(3):1-67. https://doi.org/10.18637/jss.v045. $\underline{\mathrm{i} 03}$

Younge, A., and S. Fowkes. 2003. The cape action plan for the environment: overview of an ecoregional planning process. Biological Conservation 112(1-2):15-28. https://doi.org/10.1016/ s0006-3207(02)00393-2 
Appendix 1 Details of the third-tier variables used in this study. Minimum, median, and maximum values among the studied municipalities are shown.

\begin{tabular}{|c|c|c|c|c|c|c|}
\hline First-tier variables & Code & Third-tier variables & Description & Min. & Median & Data source \\
\hline \multirow[t]{2}{*}{$\begin{array}{l}\text { Social, economic, and } \\
\text { political settings (S) }\end{array}$} & S1-F & Financial strength index & $\begin{array}{l}\text { The financial strength index is the average } \\
\text { value of the past three years where the } \\
\text { standard financial revenues calculated } \\
\text { according to the Local Tax Allocation Act are } \\
\text { divided by the standard financial needs. The } \\
\text { local public organization becomes a non- } \\
\text { granting organization of the local tax allocation } \\
\text { when the financial strength index exceeds one; } \\
\text { however, the organization is eligible to conduct } \\
\text { administrative work that exceeds standard } \\
\text { levels by the same amount that the value of } \\
\text { the index is }>1 \text {. Furthermore, organizations } \\
\text { whose financial strength index is }<1 \text { will have } \\
\text { larger reserves of financial resources for } \\
\text { calculating the ordinary allocation tax the } \\
\text { closer the financial strength index of the } \\
\text { organization is to } 1 \text {, which results in greater } \\
\text { financial resources. Values from } 2010 \text { were } \\
\text { used for the statistical values. }\end{array}$ & 0.07 & 0.77 & $\begin{array}{l}\text { 1.69 Population/economy-related data } \\
\text { by municipality, Cabinet Office } \\
\dagger\end{array}$ \\
\hline & S2-P & Population & $\begin{array}{l}\text { Values from the } 2010 \text { census were used. Units } \\
\text { are in persons. }\end{array}$ & 1765 & 249271 & $\begin{array}{l}3688773 \text { Population/economy-related data } \\
\text { by municipality } \dagger\end{array}$ \\
\hline \multirow[t]{10}{*}{ Resource systems (RS) } & RS31-P & Area of plantation forest & $\begin{array}{l}\text { Area of plantation forest in the standardized } \\
\text { land-use classification map for the whole of } \\
\text { Japan. Units are in } \mathrm{m}^{2} \text {. }\end{array}$ & 0 & 8655220 & $\begin{array}{l}773446598 \text { Standardized land-use } \\
\text { classification map for the whole } \\
\text { of Japan } \ddagger\end{array}$ \\
\hline & RS32-N & $\begin{array}{l}\text { Area of natural, secondary, and other } \\
\text { forest }\end{array}$ & $\begin{array}{l}\text { Areas of natural forest, secondary forest, and } \\
\text { other forest in the standardized land-use } \\
\text { classification map for the whole of Japan. Units } \\
\text { are in } \mathrm{m}^{2} \text {. }\end{array}$ & 0 & 42523730 & $\begin{array}{l}572571755 \text { Standardized land-use } \\
\text { classification map for the whole } \\
\text { of Japan } \ddagger\end{array}$ \\
\hline & RS33-C & Area of cultivated meadow & $\begin{array}{l}\text { Area of cultivated meadow in the standardized } \\
\text { land-use classification map for the whole of } \\
\text { Japan. Units are in } \mathrm{m}^{2} \text {. }\end{array}$ & 0 & 1807094 & $\begin{array}{l}32958332 \text { Standardized land-use } \\
\text { classification map for the whole } \\
\text { of Japan } \neq\end{array}$ \\
\hline & RS34-N & $\begin{array}{l}\text { Area of natural, secondary, and other } \\
\text { grassland }\end{array}$ & $\begin{array}{l}\text { Area of natural grassland, including the areas } \\
\text { dominated by forbs and shrubs, secondary } \\
\text { grassland, and other grassland (including sasa } \\
\text { grassland) in the standardized land-use } \\
\text { classification map for the whole of Japan. Units } \\
\text { are in } \mathrm{m}^{2} \text {. }\end{array}$ & 0 & 3452281 & $\begin{array}{l}115721316 \text { Standardized land-use } \\
\text { classification map for the whole } \\
\text { of Japan } \ddagger\end{array}$ \\
\hline & RS35-P & Area of paddy field & $\begin{array}{l}\text { Area of paddy fields in the standardized land- } \\
\text { use classification map for the whole of Japan. } \\
\text { Units are in } \mathrm{m}^{2} \text {. }\end{array}$ & 0 & 23367465 & $\begin{array}{l}386285481 \text { Standardized land-use } \\
\text { classification map for the whole } \\
\text { of Japan } \ddagger\end{array}$ \\
\hline & RS36-C & Area of other cultivated land & $\begin{array}{l}\text { Areas of farmland, roadside, tea plantations, } \\
\text { and nursery gardens in the standardized land- } \\
\text { use classification map for the whole of Japan. } \\
\text { Units are in } \mathrm{m}^{2} \text {. }\end{array}$ & 0 & 9937826 & $\begin{array}{l}188817333 \text { Standardized land-use } \\
\text { classification map for the whole } \\
\text { of Japan } \ddagger\end{array}$ \\
\hline & RS37-M & Area of wetland and open water & $\begin{array}{l}\text { Areas of marshes, waterside, seaside, and open } \\
\text { water in the standardized land-use } \\
\text { classification map for the whole of Japan. Units } \\
\text { are in } \mathrm{m}^{2} \text {. }\end{array}$ & 0 & 3658439 & $\begin{array}{l}188189854 \text { Standardized land-use } \\
\text { classification map for the whole } \\
\text { of Japan } \ddagger\end{array}$ \\
\hline & RS38-C & Coast & $\begin{array}{l}\text { Coast was determined according to whether } \\
\text { the municipality was adjcent to the ocean or } \\
\text { not from the national land value information. } 1 \text { : } \\
\text { presence } 0 \text { : absence. }\end{array}$ & 0 & 0 & $\begin{array}{l}1 \text { Administrative area data, national } \\
\text { land value information } \S\end{array}$ \\
\hline & RS4-D & Densely inhabited district & $\begin{array}{l}\text { Densely inhabited districts were the } \\
\text { proportion of regions with a high population } \\
\text { density within municipal precincts. }\end{array}$ & 0.0 & 8.28 & $\begin{array}{l}\text { 100.0 Densely inhabited district data, } \\
\text { national land value information I }\end{array}$ \\
\hline & RS5-N & Net primary production & $\begin{array}{l}\text { Calculated from 3D mesh data by Dr. Oguro } \\
\text { and Dr. Sasai. Units are gC/year. }\end{array}$ & -188189854 & 2002082595 & $\begin{array}{l}157003018473 \text { Calculations from Dr. Oguro and } \\
\text { Dr. Sasai (Oguro \& Sasai et al., } \\
\text { unpublished) }\end{array}$ \\
\hline \multirow[t]{3}{*}{ Resource units (RU) } & RU41-A & Agricultural products & $\begin{array}{l}\text { Agricultural production is the amount obtained } \\
\text { by multiplying the annual production quantity } \\
\text { for each item by the farmer's household sales } \\
\text { price for that item. Values from } 2006 \text { were used } \\
\text { for statistical values. Units are } 1,000,000 \text { yen. }\end{array}$ & 0 & 4195 & $\begin{array}{l}65530 \text { Agricultural output by } \\
\text { municipality (estimated) }\end{array}$ \\
\hline & $\mathrm{RU} 42-\mathrm{W}$ & Woody products & $\begin{array}{l}\text { Woody production is the sum of the } \\
\text { manufactured goods shipment value of wood, } \\
\text { wood products, and furniture; processing fee } \\
\text { income; other income; and shipment value of } \\
\text { waste and scraps output from the } \\
\text { manufacturing process. Values from } 2010 \text { were } \\
\text { used for statistical values. Units are } 10,000 \text { yen. }\end{array}$ & 0 & 61103 & $\begin{array}{l}2929482 \text { Industrial statistical survey, } 2010 . \\
\text { Confirmed report, Municipal } \\
\text { Edition \# }\end{array}$ \\
\hline & RU43-F & Catch of fish & $\begin{array}{l}\text { Catch of fish shows the amount of aquatic } \\
\text { animals and plants caught on the sea surface. } \\
\text { Values from } 2010 \text { are used for statistical values. } \\
\text { Units are t. }\end{array}$ & 0 & 0 & $\begin{array}{l}44103 \text { Fisheries/aquaculture } \\
\text { production statistics, sea-level } \\
\text { catch production statistics } \\
\text { survey } \dagger \dagger\end{array}$ \\
\hline \multirow[t]{2}{*}{ Governance systems (GS) } & GS2-N & $\begin{array}{l}\text { NPO participated in the LBSAP } \\
\text { committee }\end{array}$ & $\begin{array}{l}\text { Number of NPOs included among LBSAP } \\
\text { committee members. }\end{array}$ & 0 & 2.5 & 9 Questionnaire survey \\
\hline & GS31-R & $\begin{array}{l}\text { Number of cooperated national and local } \\
\text { governments }\end{array}$ & $\begin{array}{l}\text { How many administrative organizations } \\
\text { cooperated during the formulation of the }\end{array}$ & 1 & 2 & 14 Questionnaire survey \\
\hline
\end{tabular}

LBSAP? 
GS6-C Presence of an implementation Was an implementation committee established committee of LBSAP

GS7-B Bylaw related to biodiversity conservation

GS81-M Monitoring of natural environment

GS82-M Monitoring of ecosystem service (1) or not established (0) after the formulation of the LBSAP?

Were bylaws related to biodiversity

conservation created (1) or not created (0) after the formulation of the LBSAP?

Were surveys/research for determining the situation of the natural environment (e.g.,

ecosystem, biota, distribution of organisms)

shown (1) or not shown (0) as measures for the LBSAP?

Were surveys/research for determining the situation of ecosystem services (e.g., local natural resources, or methods for its use) shown (1) or not shown (0) as measures for the LBSAP?

Were surveys on the natural environment and surveys/research relating to ecosystem services implemented with the participation of local residents (1) or not (0)?

Number of municipal officials involved in the formulation of the LBSAP.

\begin{tabular}{lll}
\hline Actors (A) & A11-S & Number of municipal officials involved \\
A12-C & $\begin{array}{l}\text { Number of LBSAP committee members } \\
\text { A21-D }\end{array}$ & $\begin{array}{l}\text { Diversity of the LBSAP committee } \\
\text { members }\end{array}$
\end{tabular}

A22-E Diversity of experts in the LBSAP committee

Number of LBSAP committee members.

Of the 11 divisions of committee members (1: head or sub-head of local government, 2: administration, 3: legislators, 4: environmental council committee members, 5 . local governments/neighborhood associations, 6 NPOs/citizen groups/public-interest corporations/voluntary groups, 7: businesses, 8: agricultural/forestry/fishery industry groups, 9: experts, 10: citizens, 11: other), how many divisions appeared as LBSAP members? Of the LBSAP committee members, the number of specialized fields among experts.

A23-0 Number of municipal sections involved Number of municipal sections involved in the formulation of the LBSAP.

A51-G Number of influential organizations and people

A52-L Significant influence of the mayor

Number of influential organizations and people on the LBSAP description content.

Whether the mayor had an impact on LBSAP description content (1) or not (0).

A71-T Consciousness of traditional knowledge

of incorporating widsom and technology of natural management inherited across generations into the promotion of the LBSAP. This was evaluated on a five-point scale (5: very necessary, 4: somewhat necessary, 3: cannot be said either way, 2: not very necessary, 1 : not necessary at all).

A72-L Consciousness of local knowledge

Thought of incorporating wisdom and technology of region-specific natural management and use methods of natura resources into the promotion of LBSAP. This was evaluated on a five-point scale (5: very necessary, 4: somewhat necessary, 3: cannot be said either way, 2: not very necessary, 1: no necessary at all).

A73-T Diversity of traditional knowledge

Amount of traditional knowledge used in the LBSAP.

\begin{tabular}{lll} 
& A74-L & Diversity of local knowledge \\
\hline Action situations: & I2-A & Announcement of the progress
\end{tabular}

Amount of local knowledge used in the LBSAP.

Achievement status and evaluation results of

BSAP are (1) or are not (0) published in white papers, reports, and websites.

131-F Number of meetings held in the LBSAP Number of meetings held by the LBSAP committee committee.

132-M Informal meetings other than the LBSAP Informal meetings other than the LBSAP committee meeting

133-0 Overtime works of municipal officials committee meetings. Units are in $h$

Overtime hour ranking of municipal officials involved in the formulation of LBSAP. This was evaluated on a five-point scale $(5$ : constant overtime, 4: regular overtime, 3: occasional overtime, 2: almost entirely completed during working hours, 1: entirely completed within working hours and able to sufficiently work on other tasks).

151-P Actions reinforced by the LBSAP Actions reinforced by the LBSAP.

152-B Actions reinforced by the LBSAP (related Actions reinforced by the LBSAP (related to to biodiversity and environment) biodiversity and environment).

153-A Actions reinforced by the LBSAP (related Actions reinforced by the LBSAP (related to to agriculture, forestry and fishery) agriculture, forestry and fishery).

154-P Actions with a newly allocated budget Actions with a newly allocated budget due to the formulation of LBSAP.
1 LBSAP and local government HP

1 LBSAP and local government HP

1 "LBSAP Review", Ministry of the Environment $\ddagger \ddagger$

1 "LBSAP Review", Ministry of the Environment $\ddagger \ddagger$

1 "LBSAP Review", Ministry of the Environment $\ddagger \ddagger$

Questionnaire survey

46 Questionnaire surve

7 Questionnaire survey

$\begin{array}{lll} & 4 & 7 \text { Questionnaire survey }\end{array}$

10.5 Questionnaire survey

3 Questionnaire survey

6 Questionnaire surve

1 Questionnaire survey

5.0 Questionnaire survey

3.0

4.4

5.0 Questionnaire surve 


\begin{tabular}{|c|c|c|c|c|c|}
\hline 155-B & $\begin{array}{l}\text { Actions with a newly allocated budget } \\
\text { (related to biodiversity and environment) }\end{array}$ & $\begin{array}{l}\text { Actions with a newly allocated budget (related } \\
\text { to biodiversity and environment. } 10,000 \text { Yen. }\end{array}$ & 0 & 250 & 1500 Questionnaire survey \\
\hline I56-A & $\begin{array}{l}\text { Actions with a newly allocated budget } \\
\text { (related to agriculture, forestry and } \\
\text { fishery) }\end{array}$ & $\begin{array}{l}\text { Actions with a newly allocated budget (related } \\
\text { to agriculture, forestry and fishery. 10,000 Yen. }\end{array}$ & 0 & 0 & 1100 Questionnaire survey \\
\hline 157-L & All Actions in LBSAP & All actions in the LBSAP. & 8 & 47 & 186 Description of LBSAP \\
\hline 158- $N$ & $\begin{array}{l}\text { Inclusion of important ecosystems in the } \\
\text { LBSAP }\end{array}$ & $\begin{array}{l}\text { All ecosystems important to the region were } \\
\text { incorporated as actions in the LBSAP and } \\
\text { evaluated on a five-point scale (5: all } \\
\text { incorporated, 4: somewhat incorporated, 3: } \\
\text { neither fully nor not at all incorporated, 2: not } \\
\text { much incorporated, 1: not at all incorporated). }\end{array}$ & 2.0 & 4.0 & 4.4 Questionnaire survey \\
\hline $159-\mathrm{C}$ & Establishment of a biodiversity center & $\begin{array}{l}\text { A "biodiversity center", where staff and } \\
\text { facilities for collecting biodiversity information, } \\
\text { consulting, and specializing in the proposal } \\
\text { and implementation of other policies, is (1) or } \\
\text { is not (0) established. }\end{array}$ & 0 & 0 & $\begin{array}{l}1 \text { "LBSAP Review", Ministry of the } \\
\text { Environment } \ddagger \ddagger\end{array}$ \\
\hline $18-G$ & $\begin{array}{l}\text { Establishment of new organizations or } \\
\text { new participation of existing } \\
\text { organizations }\end{array}$ & $\begin{array}{l}\text { Were new organizations established or did } \\
\text { existing organizations newly participate (1) } \\
\text { owing to LBSAP formulation, or not (0)? }\end{array}$ & 0 & 1 & 1 Questionnaire survey \\
\hline I10-A & $\begin{array}{l}\text { Activeness in evaluating actions of the } \\
\text { LBSAP }\end{array}$ & $\begin{array}{l}\text { Were the actions described in the LBSAP } \\
\text { actively evaluated? Evaluated on a five-point } \\
\text { scale (5: agree, 4: agree somewhat, 3: neither } \\
\text { agree nor disagree, 2: disagree somewhat, 1: } \\
\text { disagree). }\end{array}$ & 2 & 4 & 5 Questionnaire survey \\
\hline O1-C & $\begin{array}{l}\text { Extent of awareness change among } \\
\text { citizens }\end{array}$ & $\begin{array}{l}\text { Was there a change in awareness among } \\
\text { residents owing to the formulation of the } \\
\text { LBSAP? Evaluated by a five-point scale ( } 5 \text { : very } \\
\text { large change in resident awareness, } 4 \text { : large } \\
\text { change in resident awareness, } 3 \text { : some change } \\
\text { in resident awareness, } 2 \text { : small change in } \\
\text { resident awareness, 1: no change in resident } \\
\text { awareness). }\end{array}$ & 1.2 & 3.3 & 4.6 Questionnaire survey \\
\hline $02-U$ & $\begin{array}{l}\text { Effectiveness of the LBSAP to the } \\
\text { society, economy and daily life }\end{array}$ & $\begin{array}{l}\text { Is the LBSAP effective in local society, } \\
\text { economy, and daily life? Evaluated on a five- } \\
\text { point scale (5: extremely useful, 4: very useful, } \\
\text { 3: somewhat useful, 2: not very useful, 1: not } \\
\text { useful). }\end{array}$ & 1.2 & 2.4 & 3.3 Questionnaire survey \\
\hline
\end{tabular}

Extent of awareness change among

\section{resid} BSAP? Evaluated by a five-point scale (5: very ( resident awareness, 2: small change in resident awareness, 1 : no change in resident

Is the LBSAP effective in local society, : somewhat useful, 2: not very useful, 1: not (a)

Data source:

†:https://www5.cao.go.jp/keizai-shimon/kaigi/special/future/keizai-jinkou_data.html

\$:https://www.nies.go.jp/biology/data/lu.html

$\S:$ :ttp://nlftp.mlit.go.jp/ksj/gml/datalist/KsjTmplt-N03-v2_3.html

I: http://nlftp.mlit.go.jp/ksj/gml/datalist/KsjTmplt-A16.html

I : http://www.maff.go.jp/j/tokei/kouhyou/sityoson_sansyutu/

\#:https://www.meti.go.jp/statistics/tyo/kougyo/result-2/h22/kakuho/sichoson/index.html

$\dagger \dagger:$ http://www.maff.go.jp/j/tokei/kouhyou/kaimen_gyosei/\#c

‡:https://www.env.go.jp/nature/biodic/lbsap/review.html 


\begin{tabular}{|c|c|c|c|c|c|c|}
\hline & Response variable & & & & & \\
\hline Explanatory variables & $\begin{array}{l}\text { 12-A:Announcement } \\
\text { of the progress }\end{array}$ & $\begin{array}{l}\text { I31-F:Number of } \\
\text { meetings held in the } \\
\text { LBSAP committee }\end{array}$ & $\begin{array}{l}\text { 132-M:Meeting hours } \\
\text { wihtout established } \\
\text { committee LBSAP }\end{array}$ & $\begin{array}{l}\text { 133-0:Overtime } \\
\text { works of municipal } \\
\text { officials }\end{array}$ & $\begin{array}{l}\text { I51-P:Actions } \\
\text { reinforced by the } \\
\text { LBSAP }\end{array}$ & $\begin{array}{l}\text { I52-B:Actions } \\
\text { reinforced by the } \\
\text { LBSAP (related to } \\
\text { biodiversity and } \\
\text { environment) }\end{array}$ \\
\hline
\end{tabular}

\begin{tabular}{|c|c|c|c|c|c|c|c|}
\hline & & & & & & & \\
\hline & Intercept & -0.007 & 0.051 & 0.126 & 0.063 & 0.010 & 0.020 \\
\hline S1-F & Financial strength index & 0.113 & -0.331 & -0.103 & -0.112 & 0.108 & -0.318 \\
\hline S2-P & Population & $0.425 *$ & -0.002 & 0.214 & 0.251 & 0.029 & 0.294 \\
\hline RS31-P & Area of plantation forest & 0.159 & 0.405 & -0.119 & 0.429 & -0.064 & 0.140 \\
\hline RS32-N & Area of natural, secondary, and other forest & -0.078 & -0.226 & -0.428 & -0.457 & -0.268 & 0.317 \\
\hline RS33-C & Area of cultivated mead ow & -0.323 & -0.202 & 0.034 & 0.361 & -0.125 & -0.315 \\
\hline RS34-N & Area of natural, secondary, and other grassland & -0.084 & 0.240 & 0.394 & 0.579 & 0.085 & -0.270 \\
\hline RS35-P & Area of paddy field & 0.071 & 0.228 & 0.588 & -0.171 & 0.113 & 0.561 \\
\hline RS36-C & Area of other cultivated land & 0.212 & -0.168 & 0.438 & -0.502 & -0.003 & 0.355 \\
\hline RS37-M & Area of wetland and open water & -0.215 & $-0.387 \dagger$ & -0.180 & -0.018 & -0.217 & -0.327 \\
\hline RS38-C & Coast & $-0.607 *$ & $-0.374 \dagger$ & $-0.651 *$ & -0.093 & -0.177 & 0.063 \\
\hline RS4-D & Densely inhabited district & -0.258 & 0.074 & 0.242 & 0.100 & -0.109 & 0.124 \\
\hline RU41-A & Agricultural products & -0.204 & -0.254 & -0.893 & 0.227 & -0.194 & -0.496 \\
\hline RU42-W & Woody products & 0.277 & 0.134 & 0.386 & $-0.382 \dagger$ & 0.156 & -0.018 \\
\hline RU43-F & Catch of fish & -0.027 & 0.032 & 0.169 & 0.328 & 0.172 & -0.133 \\
\hline GS2-N & NPO participated in the LBSAP committee & -0.198 & $0.317 \dagger$ & 0.030 & -0.061 & -0.010 & -0.165 \\
\hline GS31-R & Number of cooperated national and local governments & -0.013 & 0.081 & 0.323 & 0.174 & $0.396 *$ & 0.072 \\
\hline GS6-C & Presence of an implementation committee of LBSAP & -0.295 & 0.000 & -0.003 & -0.249 & -0.034 & -0.220 \\
\hline GS7-B & Bylaw related to biodiversity conservation & $0.425 *$ & 0.191 & 0.035 & 0.189 & 0.067 & 0.109 \\
\hline GS81-M & Monitoring of natural environment & -0.116 & $-0.674 *$ & -0.149 & 0.292 & 0.159 & -0.284 \\
\hline GS82-M & Monitoring of ecosystem service & -0.026 & -0.130 & 0.154 & -0.272 & 0.017 & 0.137 \\
\hline GS83-M & Monitoring by citizen & 0.105 & 0.369 & 0.073 & -0.073 & 0.018 & -0.054 \\
\hline A11-S & Number of municipal officials involved & 0.041 & 0.200 & $0.456 *$ & -0.131 & 0.043 & 0.011 \\
\hline A12-C & Number of LBSAP committee members & -0.096 & -0.091 & $0.433 \dagger$ & 0.017 & 0.003 & -0.244 \\
\hline A21-D & Diversity of the LBSAP committee members & 0.097 & -0.111 & 0.036 & 0.225 & -0.083 & 0.499 \\
\hline A22-E & Diversity of experts in the LBSAP committee & 0.150 & 0.087 & -0.019 & 0.018 & 0.064 & 0.219 \\
\hline A23-O & Number of municipal sections involved & $-0.382 *$ & -0.167 & 0.256 & -0.027 & $0.229 \dagger$ & 0.265 \\
\hline A51-G & Number of influential organizations and people & -0.145 & 0.079 & $-0.348 \dagger$ & -0.131 & -0.147 & $0.380 \dagger$ \\
\hline A52-L & Significant influence of the mayor & -0.274 & -0.091 & 0.142 & -0.146 & $0.263 \dagger$ & $-0.570 *$ \\
\hline A71-T & Consciousness of traditional knowledge & -0.024 & -0.087 & -0.342 & 0.023 & $0.540 *$ & -0.005 \\
\hline A72-L & Consciousness of local knowledge & 0.034 & $0.377 \dagger$ & $0.701 *$ & $0.438 *$ & $-0.533 *$ & -0.285 \\
\hline A73-T & Diversity of traditional knowledge & $-0.654 *$ & -0.330 & -0.027 & -0.051 & $-0.285 \dagger$ & -0.024 \\
\hline A74-L & Diversity of local knowledge & $0.683 *$ & 0.221 & -0.095 & 0.093 & 0.138 & -0.282 \\
\hline
\end{tabular}

$\dagger: 0.1<p \leqq 0.05$. 


\begin{tabular}{|c|c|c|c|c|c|c|c|}
\hline Explanatory variables & $\begin{array}{l}\text { I53-A:Actions } \\
\text { reinforced by the } \\
\text { LBSAP (related to } \\
\text { agriculture, forestry } \\
\text { and fishery) }\end{array}$ & $\begin{array}{l}\text { I54-P:Actions with a } \\
\text { newly allocated } \\
\text { budget }\end{array}$ & $\begin{array}{l}\text { I55-B:Actions with a } \\
\text { newly allocated } \\
\text { budget (related to } \\
\text { biodiversity and } \\
\text { environment) }\end{array}$ & $\begin{array}{l}\text { I56-A:Actions with a } \\
\text { newly allocated } \\
\text { budget (related to } \\
\text { agriculture, forestry } \\
\text { and fishery) }\end{array}$ & $\begin{array}{l}\text { 157-L:All Actions in } \\
\text { LBSAP }\end{array}$ & $\begin{array}{l}\text { I58-N:Inclusion of } \\
\text { important } \\
\text { ecosystems in the } \\
\text { LBSAP }\end{array}$ & $\begin{array}{l}\text { 159-C:Establishment } \\
\text { of a biodiversity } \\
\text { center }\end{array}$ \\
\hline
\end{tabular}

\begin{tabular}{|c|c|c|c|c|c|c|c|c|}
\hline & Intercent & & 010 & 017 & 0,332 & 0073 & & 00351 \\
\hline S1-F & Financial strength index & -0.081 & $\begin{array}{cc}.0 .149 \\
-0.243\end{array}$ & 0.158 & $\frac{-.509}{-0.040}$ & $-0.404 \dagger$ & $\begin{array}{cc}-0.009 \\
0.045\end{array}$ & -0.0 .1216 \\
\hline S2-P & Population & 0.189 & 0.163 & 0.034 & 0.289 & 0.171 & -0.316 & 0.1614 \\
\hline RS31-P & Area of plantation forest & 0.440 & 0.115 & -0.353 & 0.364 & -0.101 & 0.107 & 0.3323 \\
\hline RS32-N & Area of natural, secondary, and other forest & -0.481 & -0.443 & -0.030 & -0.255 & -0.340 & -0.105 & -0.2148 \\
\hline RS33-C & Area of cultivated mead ow & 0.038 & -0.061 & 0.232 & 0.227 & -0.017 & 0.183 & -0.0017 \\
\hline RS34-N & Area of natural, secondary, and other grassland & -0.038 & 0.447 & 0.478 & -0.112 & -0.198 & 0.219 & -0.2818 \\
\hline RS35-P & Area of paddy field & 0.156 & 0.640 & -0.206 & -0.238 & 0.193 & -0.437 & -0.0763 \\
\hline RS36-C & Area of other cultivated land & -0.135 & 0.039 & -0.522 & -0.556 & 0.520 & -0.559 & -0.3390 \\
\hline RS37-M & Area of wetland and open water & -0.347 & -0.157 & 0.139 & -0.288 & 0.027 & -0.073 & -0.2181 \\
\hline RS38-C & Coast & -0.124 & 0.159 & 0.313 & 0.127 & -0.121 & 0.172 & -0.2254 \\
\hline RS4-D & Densely inhabited district & -0.141 & -0.176 & 0.084 & -0.091 & -0.126 & -0.056 & -0.1386 \\
\hline RU41-A & Agricultural products & 0.212 & -0.474 & 0.555 & 0.721 & -0.472 & 0.636 & 0.1758 \\
\hline RU42-W & Woody products & -0.237 & 0.036 & 0.068 & -0.165 & 0.054 & -0.121 & -0.0134 \\
\hline RU43-F & Catch of fish & 0.125 & -0.346 & -0.058 & -0.168 & 0.182 & 0.179 & -0.1220 \\
\hline GS2-N & NPO participated in the LBSAP committee & 0.047 & -0.173 & 0.008 & 0.092 & -0.015 & -0.057 & 0.0303 \\
\hline GS31-R & Number of cooperated national and local governments & 0.083 & -0.162 & 0.212 & -0.039 & -0.050 & $0.341 \dagger$ & 0.0121 \\
\hline GS6-C & Presence of an implementation committee of LBSAP & 0.253 & 0.254 & 0.154 & 0.183 & -0.168 & 0.010 & 0.1435 \\
\hline GS7-B & Bylaw related to biodiversity conservation & -0.107 & -0.140 & -0.149 & 0.146 & -0.014 & 0.248 & $-0.3840 \dagger$ \\
\hline GS81-M & Monitoring of natural environment & 0.009 & 0.304 & 0.086 & 0.080 & 0.255 & 0.030 & -0.0562 \\
\hline GS82-M & Monitoring of ecosystem service & 0.231 & 0.104 & -0.073 & 0.431 & 0.306 & 0.178 & 0.2198 \\
\hline GS83-M & Monitoring by citizen & -0.320 & -0.393 & 0.126 & -0.444 & -0.233 & -0.313 & 0.0669 \\
\hline A11-S & Number of municipal officials involved & 0.211 & -0.096 & -0.078 & 0.158 & 0.022 & $0.375 \dagger$ & 0.1453 \\
\hline A12-C & Number of LBSAP committee members & -0.014 & -0.340 & 0.076 & -0.085 & -0.313 & 0.182 & -0.3618 \\
\hline A21-D & Diversity of the LBSAP committee members & -0.057 & 0.233 & -0.154 & 0.037 & 0.309 & -0.384 & $0.5241 \dagger$ \\
\hline A22-E & Diversity of experts in the LBSAP committee & -0.173 & -0.059 & -0.073 & -0.057 & 0.221 & -0.075 & 0.3049 \\
\hline A23-O & Number of municipal sections involved & 0.231 & 0.182 & 0.023 & 0.248 & $0.425 *$ & -0.263 & 0.1032 \\
\hline A51-G & Number of influential organizations and people & -0.125 & 0.231 & 0.133 & -0.068 & -0.060 & -0.020 & -0.0426 \\
\hline A52-L & Significant influence of the mayor & 0.278 & -0.115 & 0.068 & 0.119 & -0.138 & 0.086 & -0.1230 \\
\hline A71-T & Consciousness of traditional knowledge & 0.013 & 0.237 & 0.237 & -0.032 & 0.350 & $0.409 \dagger$ & -0.2314 \\
\hline A72-L & Consciousness of local knowledge & -0.161 & -0.363 & -0.239 & -0.273 & -0.121 & -0.166 & 0.0599 \\
\hline A73-T & Diversity of traditional knowledge & -0.177 & 0.064 & -0.121 & -0.261 & 0.397 & 0.062 & -0.4942 \\
\hline A74-L & Diversity of local knowledge & 0.199 & -0.097 & -0.068 & 0.367 & -0.199 & 0.128 & 0.4806 \\
\hline
\end{tabular}

\footnotetext{
$\dagger: 0.1<\mathrm{p} \leqq 0.05$
} 


\begin{tabular}{|c|c|c|c|}
\hline Explanatory variables & $\begin{array}{l}\text { 18-G:Establishment } \\
\text { of new organizations } \\
\text { or new participation } \\
\text { of existing } \\
\text { organizations }\end{array}$ & $\begin{array}{l}\text { I10-A:Activeness in } \\
\text { evaluating actions of } \\
\text { the LBSAP }\end{array}$ & $\begin{array}{l}\text { O1-C: Extent of } \\
\text { awareness change } \\
\text { among citizens }\end{array}$ \\
\hline
\end{tabular}

\begin{tabular}{|c|c|c|c|c|}
\hline & Intercept & 0.144 & -0.006 & 0.086 \\
\hline S1-F & Financial strength index & 0.051 & 0.194 & -0.022 \\
\hline S2-P & Population & 0.154 & 0.070 & 0.138 \\
\hline RS31-P & Area of plantation forest & 0.522 & -0.191 & 0.102 \\
\hline RS32-N & Area of natural, secondary, and other forest & 0.357 & 0.168 & -0.487 \\
\hline RS33-C & Area of cultivated mead ow & 0.226 & -0.039 & -0.012 \\
\hline RS34-N & Area of natural, secondary, and other grassland & -0.287 & -0.534 & 0.486 \\
\hline RS35-P & Area of paddy field & -0.758 & 0.615 & 0.735 \\
\hline RS36-C & Area of other cultivated land & -0.931 & 0.671 & 0.079 \\
\hline RS37-M & Area of wetland and open water & 0.097 & 0.004 & -0.174 \\
\hline RS38-C & Coast & -0.002 & 0.050 & -0.296 \\
\hline RS4-D & Densely inhabited district & -0.100 & 0.085 & 0.190 \\
\hline RU41-A & Agricultural products & 0.955 & -0.707 & -0.798 \\
\hline RU42-W & Woody products & -0.053 & -0.285 & 0.013 \\
\hline RU43-F & Catch of fish & -0.014 & 0.037 & 0.008 \\
\hline GS2-N & NPO participated in the LBSAP committee & -0.042 & -0.070 & 0.181 \\
\hline GS31-R & Number of cooperated national and local governments & 0.026 & 0.014 & -0.024 \\
\hline GS6-C & Presence of an implementation committee of LBSAP & 0.209 & 0.068 & 0.089 \\
\hline GS7-B & Bylaw related to biodiversity conservation & -0.234 & 0.188 & -0.034 \\
\hline GS81-M & Monitoring of natural environment & 0.049 & -0.021 & 0.010 \\
\hline GS82-M & Monitoring of ecosystem service & 0.028 & -0.057 & 0.040 \\
\hline GS83-M & Monitoring by citizen & -0.046 & -0.037 & -0.137 \\
\hline A11-S & Number of municipal officials involved & -0.074 & -0.014 & -0.024 \\
\hline A12-C & Number of LBSAP committee members & 0.052 & 0.053 & -0.085 \\
\hline A21-D & Diversity of the LBSAP committee members & -0.007 & -0.130 & 0.345 \\
\hline A22-E & Diversity of experts in the LBSAP committee & 0.011 & -0.193 & 0.136 \\
\hline A23-O & Number of municipal sections involved & -0.039 & -0.127 & 0.248 \\
\hline A51-G & Number of influential organizations and people & 0.006 & $-0.370 *$ & -0.007 \\
\hline A52-L & Significant influence of the mayor & 0.211 & 0.059 & 0.163 \\
\hline A71-T & Consciousness of traditional knowledge & -0.175 & $0.451 *$ & 0.138 \\
\hline A72-L & Consciousness of local knowledge & 0.076 & -0.216 & $0.429 *$ \\
\hline A73-T & Diversity of traditional knowledge & 0.252 & 0.062 & $0.371 *$ \\
\hline A74-L & Diversity of local knowledge & -0.287 & 0.020 & -0.080 \\
\hline
\end{tabular}

$*: p<0.05$

$\dagger: 0.1<\mathrm{p} \leqq 0.05$. 


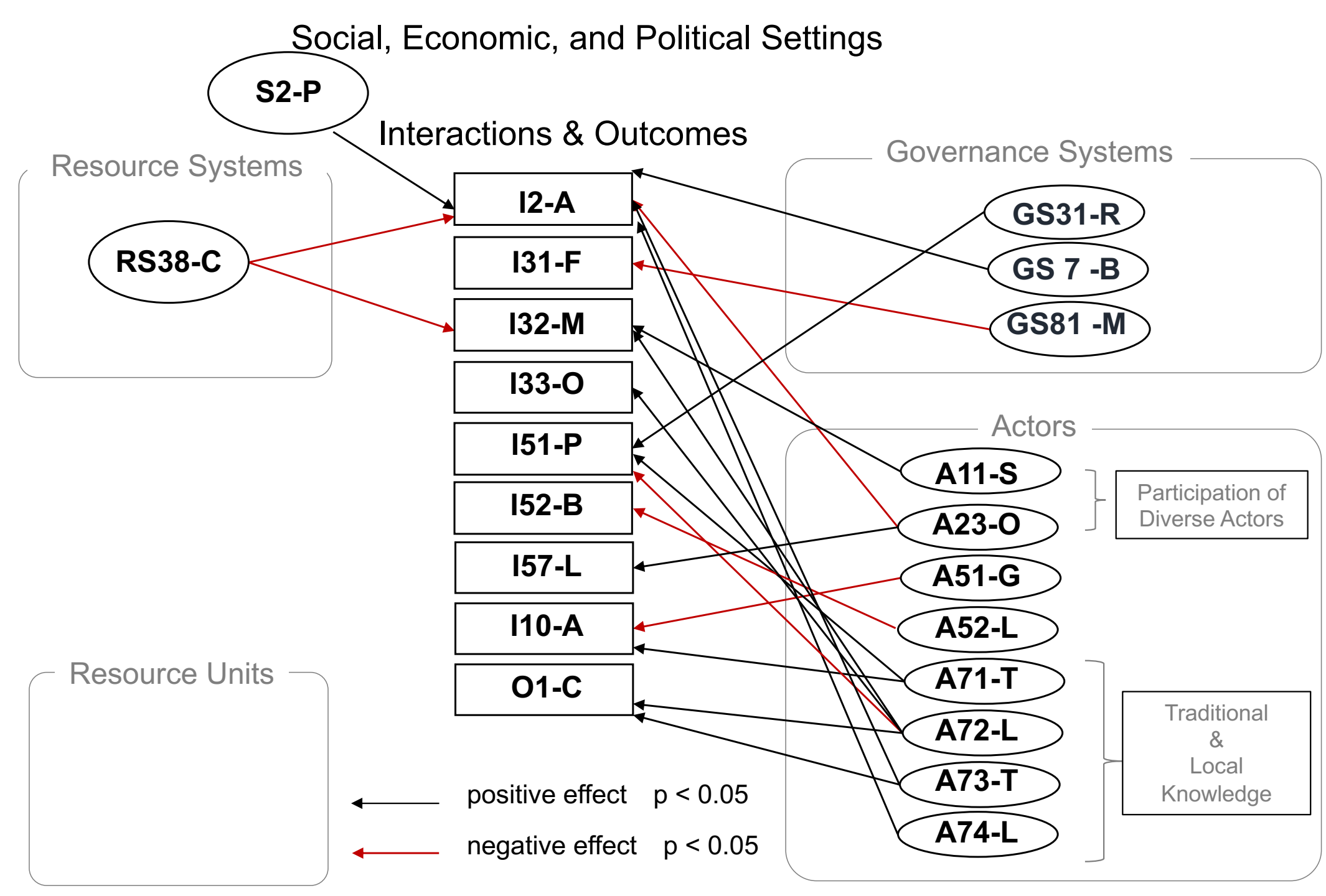

\begin{abstract}
Appendix 3 Results of the multiple regression analysis for variables related to interactions and outcomes of the social-ecological system framework as response variables. Only the significant and marginally significant relationships with variables are shown here. Full results are in Appendix 2. I2 - A: Announcement of the progress, I31 - F: Number of meetings held in the LBSAP committee, I32 -M: I Informal meetings other than the LBSAP committee meetings, I33 - O: Overtime works of municipal officials, I51 - P: Actions reinforced by the LBSAP, I52 - B: Actions reinforced by the LBSAP (related to biodiversity and environment), I57 - L: All Actions in LBSAP, I10 - A: Activeness in evaluating actions of the LBSAP, O1 - C: Extent of awareness change among citizens, RS38 - C: Coast, GS31 - R: Number of cooperated national and local governments, GS7 - B: Bylaw related to biodiversity conservation, GS81 M: Monitoring of natural environment ,A11 - S: Number of municipal officials involved, A23 - O: Number of municipal sections involved, A51- G: Number of influential organizations and people, A52- L: Significant influence of the mayor, A72 - L: Consciousness of local knowledge, A73 - T: Diversity of traditional knowledge, A74 - L: Diversity of local knowledge, S2-P: Population.
\end{abstract}




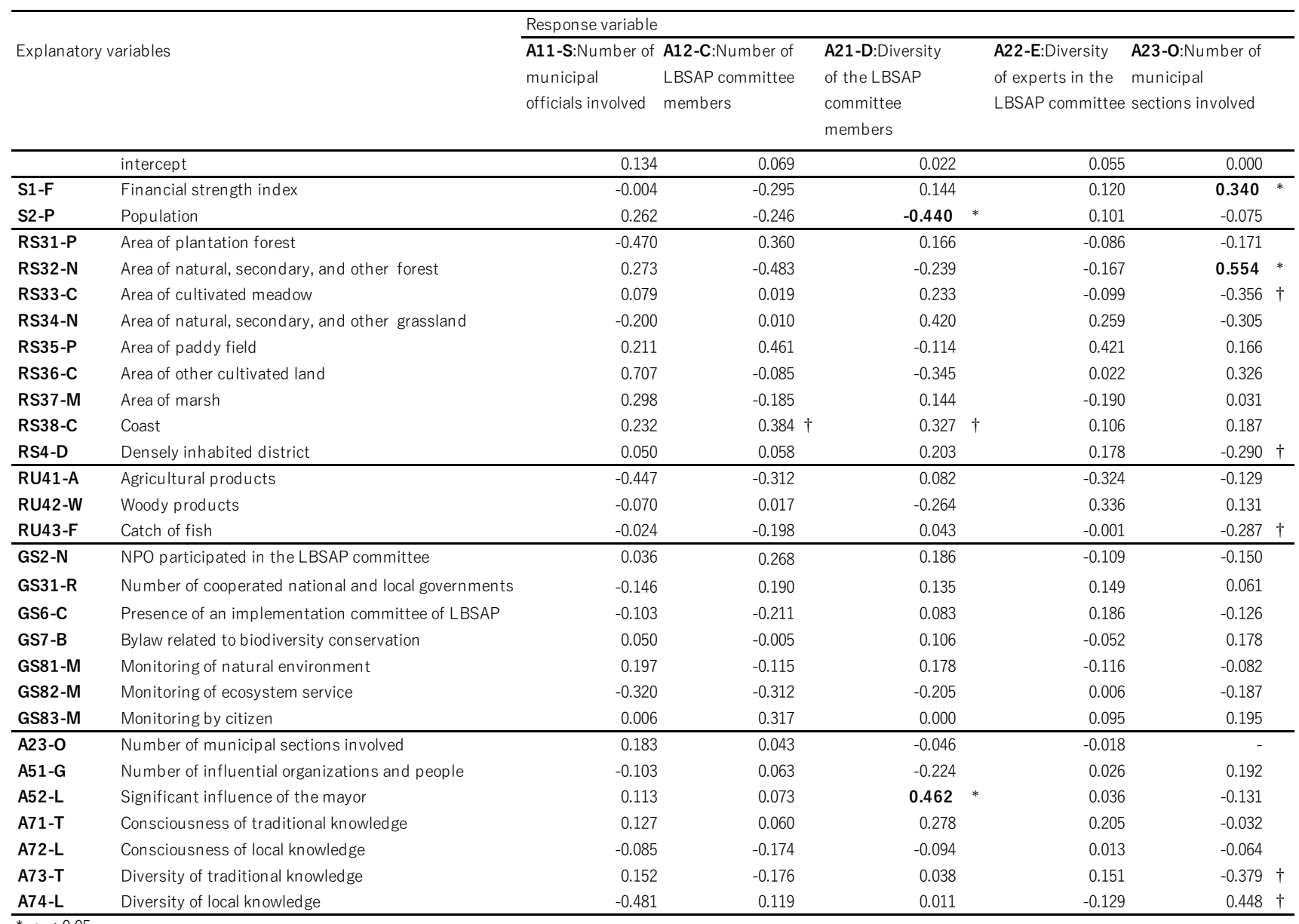

$*: p<0.05$

$\dagger: 0.10<p \leqq 0.05$

-:not included. 
Appendix 5 Results of the multiple regression analysis for variables related to traditional knowledge and local knowledge as response variables. Partial regression coefficients are

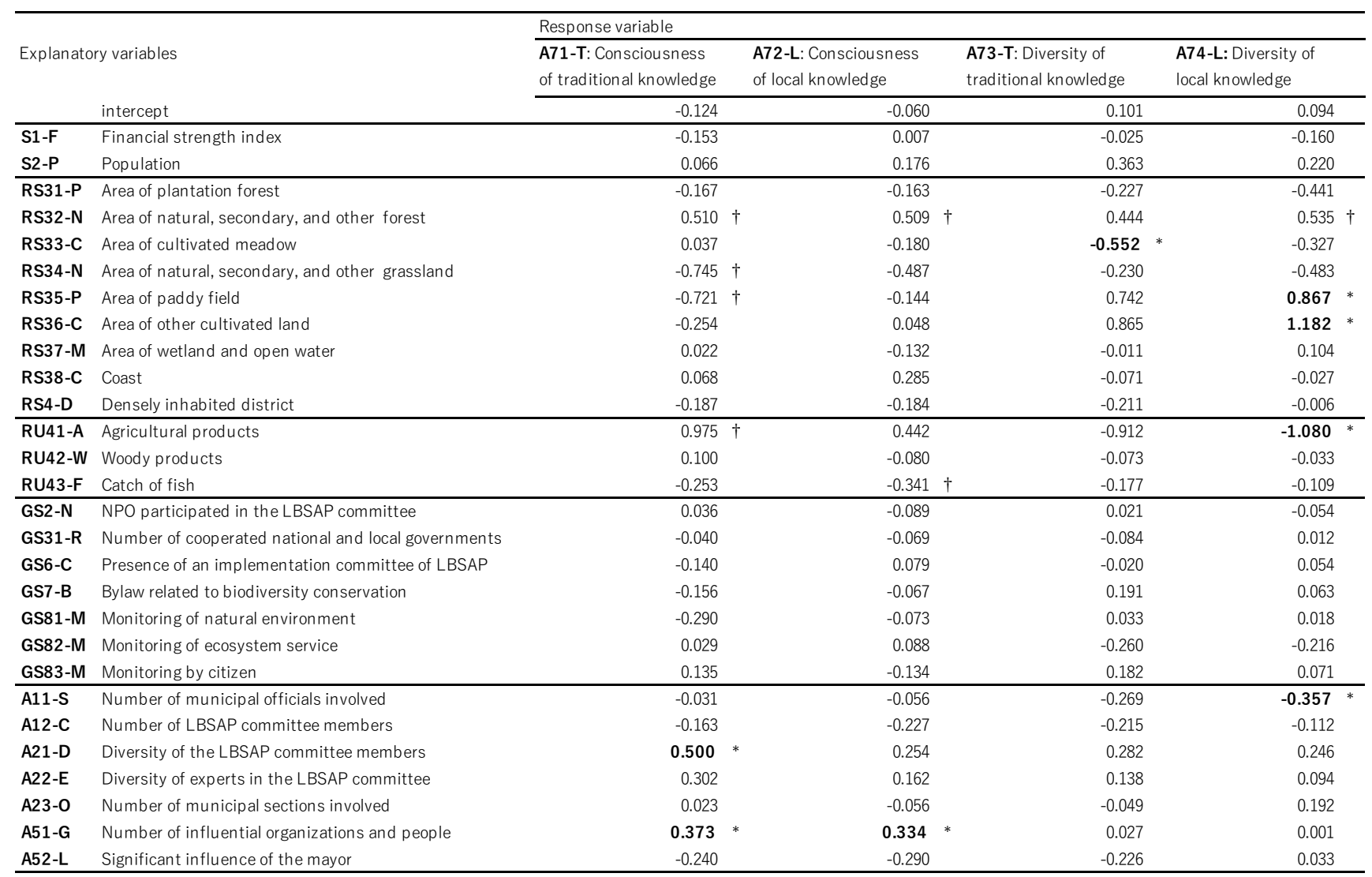

$*: p<0.05, \dagger: 0.10<p \leqq 0.05$

$\dagger: 0.10<p \leqq 0.05$. 
(A)

Somewhat unnecessary 3\% No answer 7\%

Neither necessary

nor unnecessary

$8 \%$

(C)

Somewhat unnecessary 1\% No answer 4\%

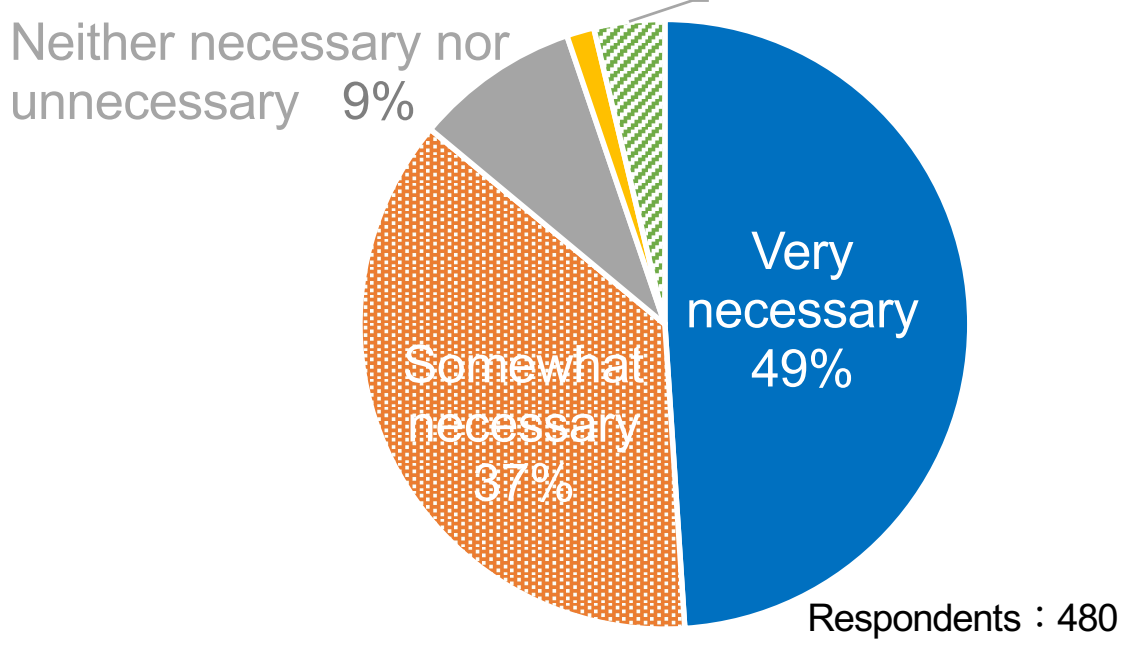

Very

necessary

$47 \%$
(B)

Information collected, but not No answer 3\% organized to be used $1 \%$

Information was not well. collected $9 \%$

Respondents:480

\section{Don't know how to use} the information 25\%

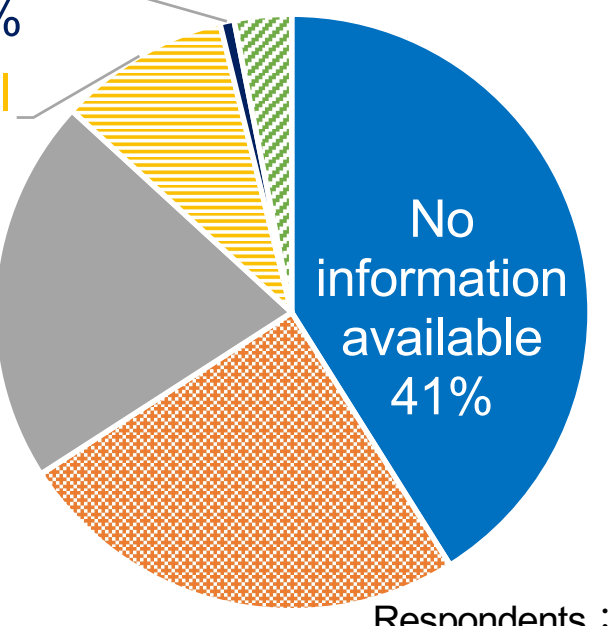

$: 129$

(D)

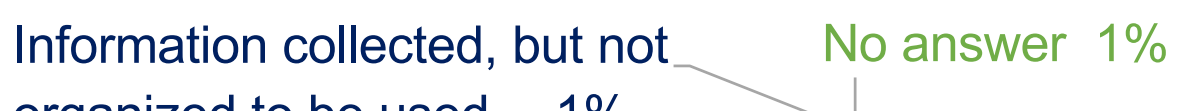
organized to be used $1 \%$

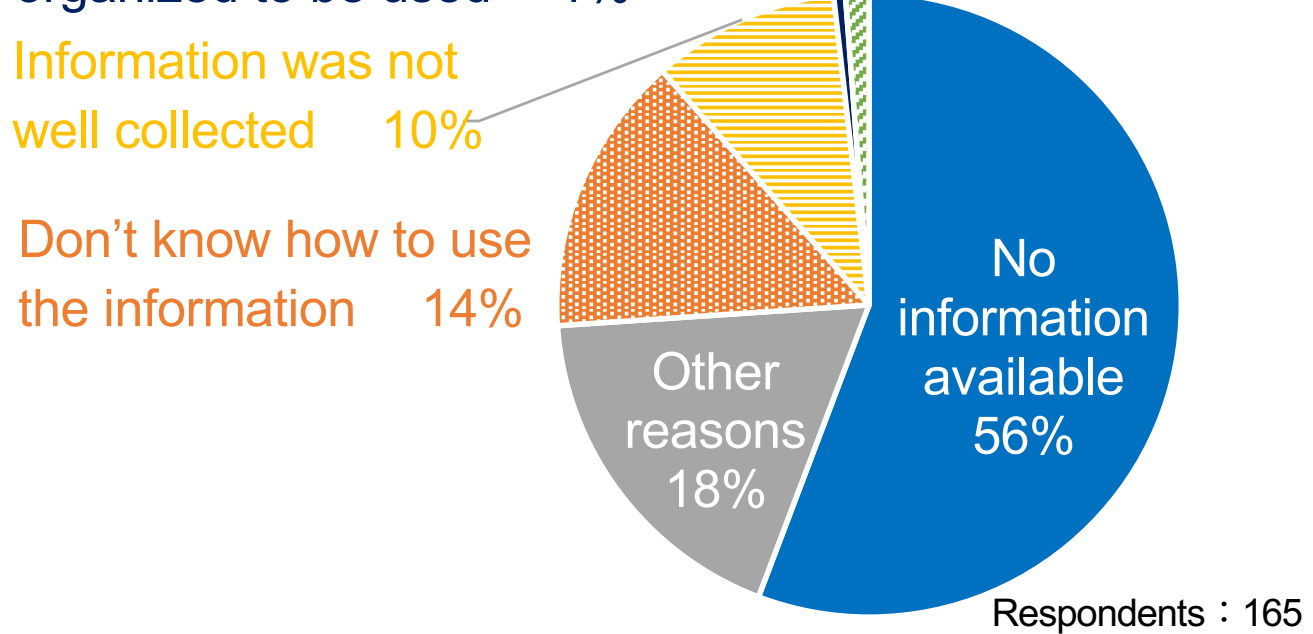

Appendix 6 Awareness of the importance of traditional and local knowledge in LBSAPs, and reasons for which traditional and local knowledge was not used in LBSAPs. A high degree of awareness existed regarding the importance of incorporating traditional knowledge (A) or local knowledge (C) into LBSAPs. The lack of information or limited understanding was often expressed as reasons for not using traditional knowledge (B) or local knowledge (D) in LBSAPs. 